\title{
Fabrication and Characterization of $\mathrm{Ni}-$, Co-, and $\mathrm{Rb}$-Incorporated $\mathrm{CH}_{3} \mathrm{NH}_{3} \mathrm{Pbl}_{3}$ Perovskite Solar Cells
}

\author{
ATSUSHI SUZUKI, ${ }^{1,2}$ MARI OE ${ }^{1}$ and TAKEO OKU ${ }^{1}$ \\ 1.-Department of Materials Science, The University of Shiga Prefecture, 2500 Hassaka, \\ Hikone, Shiga 522-8533, Japan. 2.—e-mail: suzuki@mat.usp.ac.jp
}

Ni- and Co-incorporated $\mathrm{CH}_{3} \mathrm{NH}_{3} \mathrm{PbI}_{3}$ perovskite solar cells were fabricated and characterized to optimize the photovoltaic and optical properties related to surface morphology, crystal growth and orientation, and electronic structures. Partially replacing $\mathrm{Pb}$ with $\mathrm{Ni}$ or $\mathrm{Co}$ in the perovskite crystals improved the photovoltaic performance and carrier mobility based on the effective mass in the band structure. In particular, the addition of both $\mathrm{Ni}$ and $\mathrm{Rb}$ compounds to perovskite improved the long-term stability of the photovoltaic cells, which depended on surface modification and coverage, crystal growth, and the high (100) orientation in the perovskite layer. The short-circuit current density of the cells was increased by promoting the generation and mobility of photoinduced carriers, which were inversely proportional to the effective mass ratio. Electron correlation was associated with the promotion of charge transfer owing to the hybridization between the $3 d$ orbitals of $\mathrm{Ni}$ and the $5 p$ orbitals of the I atoms near the valence band state.

Key words: Perovskite solar cell, nickel, cobalt, rubidium, density functional theory

\section{INTRODUCTION}

Inorganic-organic hybrid perovskite solar cells based on mixed-cation and halogen lead hybrid perovskite compounds have been used for practical photovoltaic devices with excellent performance, including high open-circuit voltage $\left(V_{\text {oc }}\right)$, shortcircuit current density $\left(J_{\mathrm{sc}}\right)$, power conversion efficiency $(\eta)$, and external quantum efficiency (EQE) ${ }^{1,2}$ The photovoltaic performance and optical properties of perovskite-based solar cells ${ }^{3}$ depend on perovskite crystal growth, orientation, and elemental composition, ${ }^{4-6}$ type of cell, ${ }^{4}$ morphology, optical absorption coefficient, and carrier mobility, which are related to the excited carrier diffusion length and life in the active and hole-transporting layer (HTL). The general chemical formula of perovskite compounds is $\mathrm{ABX}_{3}$, where $\mathrm{A}$ and $\mathrm{B}$ are cations and $\mathrm{X}$ is an anion. In cubic perovskite crystals, the $\mathrm{B}$

(Received June 29, 2020; accepted January 18, 2021; published online February 11, 2021) cations are surrounded by $\mathrm{X}$ anions and the $\mathrm{A}$ cations present octahedral coordination. Perovskite crystals consist of $\mathrm{Pb}$ atoms at the $\mathrm{B}$-sites, halogen anions (I, $\mathrm{Cl}$, and $\mathrm{Br}$ ) at the $\mathrm{X}$-sites, ${ }^{5,6}$ and organic cations such as methyl ammonium ( $\mathrm{MA}, \mathrm{CH}_{3} \mathrm{NH}_{3}$ ), formamidinium $\left(\mathrm{FA}, \mathrm{CH}_{3}\left(\mathrm{NH}_{2}\right)_{2}\right)$, and guanidinium $\left(\mathrm{GA}, \mathrm{C}\left(\mathrm{NH}_{2}\right)_{3}\right)^{7}$ at the A-sites. To improve the longterm stability of perovskite-based photovoltaic cells, partial substitution of FA, GA, ${ }^{8,9}$ ionic liquid additives, ${ }^{10}$ halogen anions $\left(\mathrm{I}^{-}, \mathrm{Cl}^{-}\right.$, and $\left.\mathrm{Br}^{-}\right),{ }^{11}$ alkali metal ions $\left(\mathrm{Na}^{+}, \mathrm{K}^{+}, \mathrm{Rb}^{+}\right.$, and $\left.\mathrm{Cs}^{+}\right){ }^{12-16}$ metals ( $\mathrm{Sn}$ and $\mathrm{Pb}),{ }^{17}$ transition metals $\left(\mathrm{Cu},{ }^{18-22} \mathrm{Co},{ }^{23,24} \mathrm{Ni},{ }^{25}\right.$ $\mathrm{Zn},{ }^{26,27} \mathrm{Cr},{ }^{28} \mathrm{Y}, \mathrm{Fe}$, and $\mathrm{Mn}^{29}$ in perovskite crystals has been investigated. The tolerance factor varied with the effective ionic radii of transition metals and was used to predict the thermodynamic stability of single perovskite cubic crystals. ${ }^{30}$

Transition metal-incorporated perovskite crystals promote photoinduced carrier generation and diffusion and increase the optical absorption coefficient and wavelength related to the $E_{\text {g }}$ of perovskites. ${ }^{18-29}$ Uniform crystalline films without defects and pinholes effectively promote carrier generation and 
diffusion without carrier recombination, which improves the long-term stability of perovskite-based photovoltaic cells under atmospheric conditions. For example, the addition of small amounts of $\mathrm{Co}^{23,24}$ or $\mathrm{Ni}^{25}$ to perovskite crystals improved crystal nucleation and growth by increasing surface coverage, which caused an increase in photocurrent by suppressing the leakage current near the interface between the crystal domains. The immobilization of defects by suppressing carrier traps was performed to improve photovoltaic performance. ${ }^{24,25}$ Based on electronic structural analysis, carrier mobility related to the effective mass was expected by the band dispersion of the perovskite crystals along the direction of the wave vector. Additionally, perturbation of crystal field splitting via the Jahn-Teller effect is an important factor for controlling the splitting of the degenerate energy levels of the $3 d$ orbitals and charge transfer between the $3 d$ orbitals of transition metals and the $5 p$ orbitals of halogen atoms in the coordination structure. ${ }^{18-21,26-31}$ Recently, the addition of small amounts of $\mathrm{Eu}^{3+}-\mathrm{Eu}^{2+}$ ions to perovskite crystals improved the long-term stability of perovskitebased photovoltaic cells by decreasing the number of internal defects and suppressing degradation via redox shuttle reactions. ${ }^{32}$ Experimental results and theoretical first-principle density functional theory (DFT) calculations revealed that the electronic structure of lanthanide- and actinide-containing perovskite compounds could be optimized by tuning their photovoltaic and optical properties. ${ }^{31,32} \mathrm{Eu}$ and acetate codoped perovskite solar cells with high conversion efficiency and stability have been fabricated and characterized. $^{33}$

Furthermore, the incorporation of small amounts of alkali metals, such as $\mathrm{K}, \mathrm{Na}, \mathrm{Rb}$, and $\mathrm{Cs}$, in uniform crystalline perovskite films, crystal growth, and suppression of pinholes and defects improved the photovoltaic performance of perovskite-based solar cells. Photoinduced current density-voltage $(J-V)$ curve analysis, infrared (IR) and Raman spectroscopy, ${ }^{34-36}$ nuclear magnetic resonance (NMR) spectroscopy, ${ }^{37-40}$ scanning probe microscopy with energy-dispersive x-ray spectroscopy, ${ }^{41}$ $\mathrm{x}$-ray diffraction (XRD) analysis, crystal structure analysis, and angle-resolved photoemission spectroscopy ${ }^{42}$ have been used to optimize the photovoltaic and optical properties of perovskite-based solar cells. The electronic structure, band gap $\left(E_{\mathrm{g}}\right)$, effective mass of electrons $\left(m_{\mathrm{e}}{ }^{*}\right)$ and holes $\left(m_{\mathrm{h}}{ }^{*}\right)$, total density of states and partial density of states (PDOS) have been analyzed using first-principles DFT calculations. ${ }^{43-46}$ Electron correlation was associated with the charge transfer from the alkali metal to the $\mathrm{Pb}$ atom near the conduction band (CB) and ligand-to-metal charge transfer from the I atom to the metal near the valence band (VB). The electronic mechanism was based on the promotion of carrier generation, diffusion in the perovskite layer, and crystal growth and orientation, which were expected to improve the photovoltaic performance of the cell in terms of short-circuit current density and conversion efficiency. The Gibbs free energy $(\Delta \mathrm{G})$ and entropy $(\Delta \mathrm{S})$ values suggested that thermodynamic stabilization occurred without carrier diffusion scattering as phonon effectiveness. ${ }^{30,43,44}$ The $\Delta \mathrm{S}$ value and vibration modes in the IR and Raman spectra were considered with the electron-lattice interaction as the phonon effect.

The goal of this study was to investigate the effects of the addition of transition metals on the photovoltaic and optical properties, microstructure, and electronic structure of methylammonium lead iodide $\left(\mathrm{MAPbI}_{3}\right)$ perovskite-based solar cells. The effects of adding $\mathrm{Co}, \mathrm{Ni}$, and $\mathrm{Rb}$ to $\mathrm{MAPbI}_{3}$ perovskite compounds on the long-term stability of the photovoltaic cells and on perovskite microstructure, crystal growth, and electronic structure were investigated experimentally and using first-principles DFT calculations. The photovoltaic mechanism was discussed based on the band structure using $m_{\mathrm{e}}{ }^{*}$, $m_{\mathrm{h}}{ }^{*}, E_{\mathrm{g}}$, the PDOS, and electron correlation associated with the $3 d$ hybrid orbitals of the transition metal and $5 p$ orbitals of the I atom near the VB.

\section{EXPERIMENTAL}

The schematic diagram for the fabrication of Co-, $\mathrm{Ni}$-, and $\mathrm{Rb}$-incorporated $\mathrm{MAPbI}_{3}$ perovskite solar cells is presented in Fig. 1. Fluorine-doped tin oxide (FTO) substrates (FNT1.6, $20 \mathrm{~mm} \times 20 \mathrm{~mm} \times 1.6$ $\mathrm{mm}$, Nippon Sheet Glass Company, Ltd.) were cleaned in an ultrasonic bath using acetone and methanol and were subsequently dried under a $\mathrm{N}_{2}$ flow. $\mathrm{TiO}_{x}$ precursor solutions $(0.15$ and $0.30 \mathrm{M})$ were prepared using titanium diisopropoxide bis(acetylacetonate) $(0.055$ and $0.11 \mathrm{~mL}$, respectively, Sigma-Aldrich) and 1-butanol (1 mL, Nacalai Tesque). Thereafter, the $0.15 \mathrm{M} \mathrm{TiO}$ precursor solution was spin-coated on the FTO substrate at $3000 \mathrm{rpm}$ for $30 \mathrm{~s}$ followed by annealing at $125^{\circ} \mathrm{C}$ for 5 min. Subsequently, the $0.30 \mathrm{M} \mathrm{TiO}_{x}$ precursor solution was spin-coated on the previously deposited $\mathrm{TiO}_{x}$ layer at $3000 \mathrm{rpm}$ for $30 \mathrm{~s}$ followed by annealing at $125^{\circ} \mathrm{C}$ for $5 \mathrm{~min}$. This process was performed twice, and then, the fabricated FTO substrate was sintered at $500^{\circ} \mathrm{C}$ for $30 \mathrm{~min}$ to form a compact $\mathrm{TiO}_{2}$ layer. To obtain a mesoporous $\mathrm{TiO}_{2}$ layer, $\mathrm{TiO}_{2}$ paste was prepared by mixing $\mathrm{TiO}_{2}$ powder (Aeroxide $\mathrm{TiO}_{2} \mathrm{P}-25$, Evonik Industries AG) with polyethylene glycol (PEG \#20000, Nacalai Tesque) in ultrapure water. The solution was mixed with acetyl acetone (Wako Pure Chemical Industries) and Triton X-100 (Sigma-Aldrich) for $30 \mathrm{~min}$ and was allowed to rest for $12 \mathrm{~h}$ to suppress the formation of bubbles. To prepare the electron-transporting layer, $\mathrm{TiO}_{2}$ paste was coated on the substrate by spin-coating at $2000 \mathrm{rpm}$ for $5 \mathrm{~s}$ and then at $5000 \mathrm{rpm}$ for $30 \mathrm{~s}$. The prepared cells were annealed at $120^{\circ} \mathrm{C}$ for $5 \mathrm{~min}$ and at $550^{\circ} \mathrm{C}$ for $30 \mathrm{~min}$ to form mesoporous $\mathrm{TiO}_{2}$ layers. 

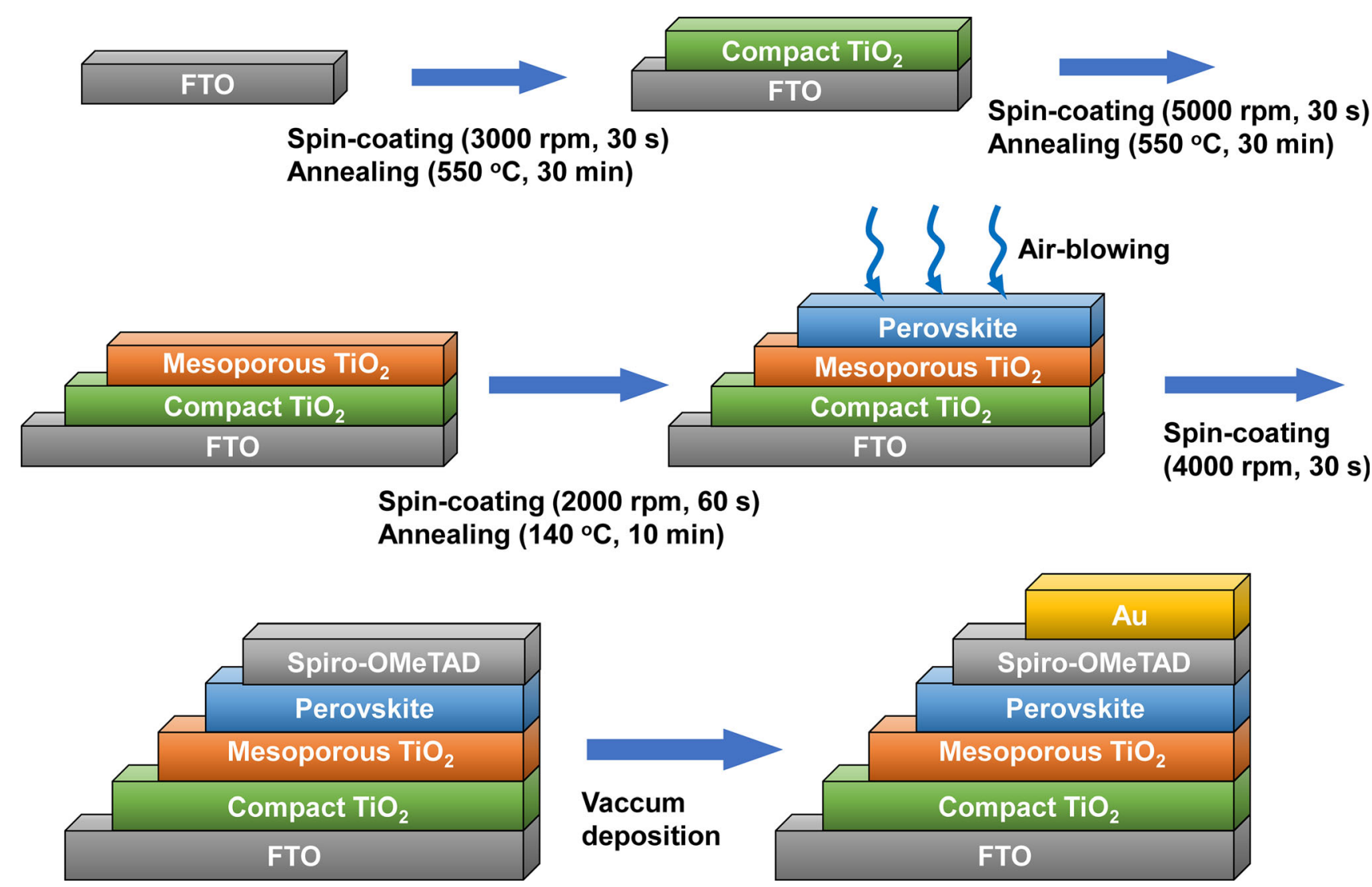

Fig. 1. Fabrication of Co-, Ni-, and Rb-incorporated $\mathrm{MAPbl}_{3}$ perovskite solar cells.

To synthesize the perovskite compounds, a solution of methylamine hydroiodide (MAI: $190.7 \mathrm{mg}$, $1.2 \mathrm{mmol}$, Tokyo Chemical Industry Co., Ltd.) and lead(II) chloride $\left(\mathrm{PbCl}_{2}, 111.2 \mathrm{mg}, 0.4 \mathrm{mmol}\right.$, SigmaAldrich) in $N, N$-dimethylformamide (500 $\mu \mathrm{L}$, Nacalai Tesque) was mixed with 1,2 , or 5 wt.\% cobalt(II) chloride $\left(\mathrm{CoCl}_{2}\right.$, Sigma-Aldrich) or nickel(II) chloride anhydrous $\left(\mathrm{NiCl}_{2}\right.$, Tokyo Chemical Industry Co., Ltd.) and rubidium iodide (RbI, Wako Pure Chemical Industries) at $60^{\circ} \mathrm{C}$ for $24 \mathrm{~h}$. Subsequently, the perovskite solution was added to the $\mathrm{TiO}_{2}$ mesoporous film via spin-coating. The spincoating speed was maintained at $1000 \mathrm{rpm}$ for $5 \mathrm{~s}$ and then at $2000 \mathrm{rpm}$ for $60 \mathrm{~s}$; moreover, a heat gun placed $25 \mathrm{~cm}$ away from the surface of the film was used to generate a $60 \mathrm{~s}$ hot air burst. After spincoating, the samples were subjected to annealing at $140^{\circ} \mathrm{C}$ for $10 \mathrm{~min}$. The HTL was prepared and spincoated as follows. A solution of $2,2^{\prime}, 7,7^{\prime}$-tetrakis[N,N-di(methoxyphenyl)amino]-9, $9^{\prime}$-spirobi-

fluorene (Spiro-OMeTAD, $36.1 \mathrm{mg}$, Wako Pure Chemical Industries) in chlorobenzene $(0.5 \mathrm{~mL}$, Wako Pure Chemical Industries) was mixed with a solution of lithium bis(trifluoromethyl sulfonyl)imide (Li-TFSI, $260 \mathrm{mg}$, Tokyo Chemical Industry Co., Ltd.) in acetonitrile $(0.5 \mathrm{~mL}$, Nacalai Tesque) for $12 \mathrm{~h}$. The solution obtained by adding 4tert-butylpyridine (14.4 $\mu \mathrm{L}$, Sigma-Aldrich) to the Spiro-OMeTAD solution was mixed with the Li-
TFSI solution $(8.8 \mu \mathrm{L})$ for $30 \mathrm{~min}$ at $70^{\circ} \mathrm{C}$. The obtained mixture was spin-coated at $2000 \mathrm{rpm}$ for $5 \mathrm{~s}$ and then at $4000 \mathrm{rpm}$ for $30 \mathrm{~s}$. All experiments were performed under atmospheric conditions. Lastly, a layer of Au was deposited via evaporation on the top side of the electrodes. The layered structure of the photovoltaic cells was denoted as FTO/TiO 2 /perovskite/Spiro-OMeTAD/Au (Fig. 1).

The $J-V$ curves of the photovoltaic cells were obtained under an illumination of $100 \mathrm{~mW} \mathrm{~cm} \mathrm{~cm}^{-2}$ using an AM 1.5 solar simulator (San-ei Electric XES-301S) at $27^{\circ} \mathrm{C}$. The solar cells were illuminated through the side of the FTO substrates, and the illuminated area was $0.090 \mathrm{~cm}^{2}$. The average power conversion efficiency $\left(\eta_{\text {ave }}\right)$ was estimated using the average of the forward and reverse values. The reverse value was used as the best efficiency. Several $J-V$ curves were obtained to determine the average and highest values. The long-term stability of the cells and changes in $\eta$ and $J_{\mathrm{sc}}$ were analyzed at $27^{\circ} \mathrm{C}$ and $20 \%$ humidity for $50 \mathrm{~d}$. The $\eta_{\text {ave }}$ values were estimated using a three-electrode system. The yield value was removed when the surface was damaged. The incident photon-to-current efficiencies of the cells were also investigated using a QE-R (Enli Technology) system. The microstructure of the perovskite thin films was observed using an Eclipse E600 (Nikon) optical microscope. The crystal structure, crystallinity, and 
lattice spacing of the perovskite thin films were measured using a D2 Phaser (Bruker) XRD system. After removing the $\mathrm{K} \alpha_{2}$ x-ray wavelength of the $\mathrm{Cu}$ target from the measured x-ray diffraction patterns, the crystallite sizes were estimated using the Scherrer formula, the Scherrer constant $(K=0.9)$, and device constant $(\beta=0.065)$. The crystal structure of each perovskite crystal was confirmed using data reported in the literature. ${ }^{30}$

The electronic structures of the perovskite crystals were single-point-calculated using the crystallographic structural data obtained from their XRD patterns. Ab initio quantum calculations were performed using the Vanderbilt ultrasoft pseudo-potentials, scalar relativistic generalized gradient approximations and Perdew-Burke-Ernzerhof (GGA-PBE) exchange-correlation functional (Quantum Espresso software) without considering the spin-orbital coupling effect. The plane-wave basis set cutoffs for the wave functions and charge density were set at 25 and $225 \mathrm{Ry}$. A uniform $k$-point grid $(4 \times 4 \times 4)$ in the Brillouin zone was used to calculate the electronic structure and PDOS. The perovskite crystals presented cubic symmetry with $P m \overline{3} m$ space group, and $2 \times 2 \times 2$ cubic supercells were constructed using the experimental lattice constant determined utilizing XRD data. In the metal-incorporated perovskite crystal unit cell model, a fraction of the $\mathrm{Pb}$ atoms at the $\mathrm{B}$-sites was substituted with $\mathrm{Co}$ or $\mathrm{Ni}$ atoms for one-atom substitution at the center of the cubic structure. Coor Ni-incorporated $\mathrm{MAPbI}_{3}$ perovskite cubic crystal models were constructed using $2 \times 2 \times 2$ supercells and the experimentally determined lattice constants, and the models were used for band calculations. The molar ratio of $\mathrm{Co}^{2+}$ or $\mathrm{Ni}^{2+}$ ions to $\mathrm{Pb}^{2+}$ ions was adjusted to $1: 8$; that is, $12.5 \%$ of $\mathrm{Pb}^{2+}$ ions were replaced with $\mathrm{Co}^{2+}$ or $\mathrm{Ni}^{2+}$ ions. The ion replacement and structural distortion caused by the difference in the ionic radii of $\mathrm{Co}^{2+}$ or $\mathrm{Ni}^{2+}$ and $\mathrm{Pb}^{2+}$ worked slightly in the isolated dilution system. The band structures, effective mass, and band gap of the Brillouin zone of the perovskite crystal lattice were analyzed along the direction of the wave vector. The path for $\mathrm{MAPbI}_{3}$ perovskite crystal was set as follows: $\Gamma\left(\begin{array}{lll}0, & 0,0) \rightarrow X(0,1 / 2,\end{array}\right.$ $0) \rightarrow M(1 / 2,1 / 2,0) \rightarrow \Gamma \rightarrow R(1 / 2,1 / 2,1 /$ 2) $\rightarrow X, M \rightarrow R$, and the path for the $\mathrm{MAPb}(\mathrm{Co}) \mathrm{I}_{3}$ and $\mathrm{MAPb}(\mathrm{Ni}) \mathrm{I}_{3}$ perovskite crystals were set as follows: $\Gamma(0,0,0) \rightarrow X(1 / 2,0,1 / 2) \rightarrow W(1 / 2,1 / 4$, $3 / 4) \rightarrow K(3 / 8,3 / 8,3 / 4) \rightarrow \Gamma \rightarrow L(1 / 2,1 / 2,1 /$ $2) \rightarrow U(5 / 8,1 / 4,5 / 8) \rightarrow W(1 / 2,1 / 4,3 / 4) \rightarrow L$ $\rightarrow K \mid U \rightarrow \mathrm{X}$. The effective $m_{\mathrm{e}}{ }^{*} / m_{0}$ and $m_{\mathrm{h}}{ }^{*} / m_{0}$ ratios, where $m_{0}$ is the mass of free electrons, were calculated using the curvature of the band dispersion curve. The Fermi energy was set to zero. The density of states (DOS) and PDOS were calculated to determine the energy level of each orbital near the VB and CB. The experimentally determined band structure of the cubic crystals was compared with the theoretical and experimental results reported in the literature.

To assess the thermodynamic stability and electron-lattice interactions as the phonon effect in the systems with added $\mathrm{Co}$ or $\mathrm{Ni}$, the thermodynamic parameters and vibration modes in the IR and Raman spectra were analyzed using hybrid DFT utilizing the unrestricted B3LYP (UB3LYP) with LANL2MB basis set (Gaussian 09). The cluster model of the perovskite crystals consisted of a cubic crystal, and its lattice constants were experimentally determined using XRD data. The metal-incorporated $\mathrm{MAPbI}_{3}$ cubic structure and $\mathrm{MAPbI}_{3}$ perovskite crystal cluster models were constructed using $2 \times 2 \times 2$ supercells, which were fixed at +8 as the positive charge of MA. The thermodynamic parameters $(\Delta \mathrm{G}$, enthalpy $(\Delta \mathrm{H})$, and $\Delta \mathrm{S})$ and the vibration modes in the IR and Raman spectra of the cluster model metal-incorporated $\mathrm{MAPbI}_{3}$ perovskite cubic crystals with $2 \times 2 \times 2$ supercells were calculated using hybrid DFT utilizing the frequency mode. The effects of incorporating Co or $\mathrm{Ni}$ atoms into the perovskite crystals on the photovoltaic properties of the perovskite-based cells were qualitatively investigated using experimental data, electronic structure, and thermodynamic properties.

\section{RESULTS AND DISCUSSION}

The photovoltaic properties of perovskite-based solar cells were investigated using the $J-V$ curves obtained under illumination. The $J-V$ curves of the solar cells featuring $\mathrm{Co}-, \mathrm{Ni}-, \mathrm{Co} / \mathrm{Rb}-$, and $\mathrm{Ni} / \mathrm{Rb}-$ incorporated $\mathrm{MAPbI}_{3}$ perovskites are presented in Fig. 2. The $J_{\mathrm{sc}}$ and $V_{\mathrm{oc}}$ values indicated that the cells presented semiconductive characteristics. The photovoltaic parameters, namely $V_{\mathrm{oc}}, J_{\mathrm{sc}}$, fill factor $(F F)$, series resistance $\left(R_{\mathrm{s}}\right)$, shunt resistance $\left(R_{\mathrm{sh}}\right)$, and $\eta$, of all analyzed cells are listed in Table I. The

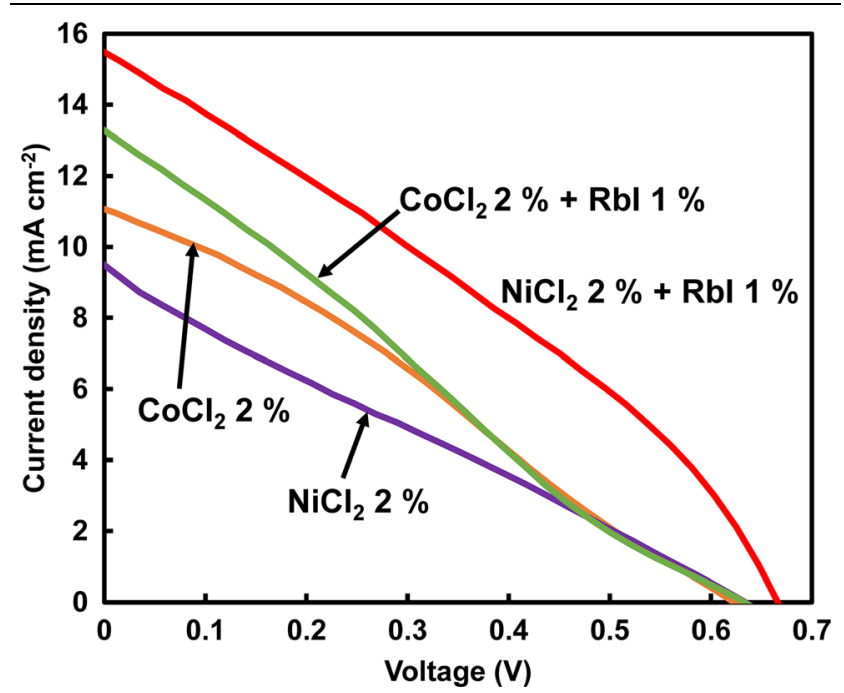

Fig. 2. $J-V$ characteristics of the perovskite solar cells with $\mathrm{CoCl}_{2}$, $\mathrm{NiCl}_{2}$ and $\mathrm{Rbl}$. 


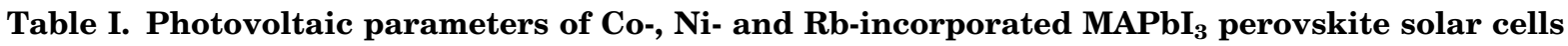

\begin{tabular}{|c|c|c|c|c|c|c|c|}
\hline Devices & $J_{\mathrm{SC}}\left(\mathrm{mA} \mathbf{c m}^{-2}\right)$ & $V_{\text {OC }}(\mathbf{V})$ & $\mathbf{F F}$ & $R_{\mathrm{s}}\left(\Omega \mathrm{cm}^{2}\right)$ & $R_{\mathrm{sh}}\left(\Omega \mathrm{cm}^{2}\right)$ & $\eta(\%)$ & $\eta_{\text {ave }}(\%)$ \\
\hline $\mathrm{MAPbI}_{3}$ & 18.2 & 0.807 & 0.503 & 7.43 & 175 & 7.40 & 6.75 \\
\hline $\mathrm{CoCl}_{2} 2 \%$ & 11.1 & 0.623 & 0.287 & 40.8 & 91.6 & 1.98 & 1.73 \\
\hline $\mathrm{NiCl}_{2} 2 \%$ & 9.49 & 0.634 & 0.248 & 47.8 & 76.4 & 1.49 & 1.31 \\
\hline $\mathrm{CoCl}_{2} 5 \%$ & 15.1 & 0.800 & 0.381 & 24.2 & 340 & 4.60 & 3.53 \\
\hline $\mathrm{NiCl}_{2} 5 \%$ & 17.2 & 0.514 & 0.343 & 16.7 & 110 & 3.04 & 2.38 \\
\hline $\mathrm{CoCl}_{2} 2 \%+\mathrm{RbI} 1 \%$ & 13.3 & 0.633 & 0.246 & 38.3 & 53.8 & 2.07 & 1.77 \\
\hline $\mathrm{NiCl}_{2} 2 \%+\mathrm{RbI} 1 \%$ & 12.5 & 0.679 & 0.401 & 13.1 & 117 & 3.40 & 3.19 \\
\hline $\mathrm{CoCl}_{2} 5 \%+\mathrm{RbI} 2 \%$ & 11.1 & 0.831 & 0.392 & 13.1 & 154 & 3.58 & 3.30 \\
\hline
\end{tabular}

addition of 2 or $5 \% \mathrm{NiCl}_{2}$ or $\mathrm{CoCl}_{2}$ to $\mathrm{MAPbI}_{3}$ perovskite affected the photovoltaic parameters and caused the $J_{\mathrm{sc}}, V_{\mathrm{oc}}, F F$, and $\eta$ values of the cells featuring Ni- or Co-incorporated $\mathrm{MAPbI}_{3}$ perovskites to be lower than those of the cells featuring $\mathrm{MAPbI}_{3}$ perovskite crystals. When $2 \% \mathrm{CoCl}_{2}$ or $\mathrm{NiCl}_{2}$ and $1 \% \mathrm{RbI}$ were co-added to $\mathrm{MAPbI}_{3}$ perovskite, the $\eta$ value of the cells increased to 2.07$3.58 \%$. $J_{\mathrm{sc}}, V_{\mathrm{oc}}$, and $R_{\mathrm{sh}}$ increased with the amount of $\mathrm{CoCl}_{2}$ when different amounts of $\mathrm{CoCl}_{2}$ and $1 \%$ RbI were co-added to $\mathrm{MAPbI}_{3}$ perovskite. The photovoltaic performance of cells was improved via surface modification and crystal growth promotion in the perovskite layer. The $J_{\mathrm{sc}}, V_{\mathrm{oc}}, F F$, and $\eta$ values were lower than those of the cells featuring tetragonal $\mathrm{MAPb}_{0.984} \mathrm{Co}_{0.016} \mathrm{I}_{3}{ }^{23,24}$ and Ni-doped MAPbI $_{3}{ }^{25}$ perovskite crystals. The replacement of $\mathrm{Pb}$ with $\mathrm{Co}$ or $\mathrm{Ni}$ affected the surface morphology and the growth of perovskite crystals and also the cubic-to-tetragonal phase transition. The photovoltaic performance of the cells featuring perovskites with added $\mathrm{Co}$ or $\mathrm{Ni}$ depended on promoting crystal growth and hindering the formation of pinholes and defects.

The EQEs of the solar cells featuring $\mathrm{Co} / \mathrm{Rb}$ - and $\mathrm{Ni} / \mathrm{Rb}$-incorporated $\mathrm{MAPbI}_{3}$ perovskite perovskites are illustrated in Fig. $3 a$ and $b$. The performance of these cells was compared with that of the cell featuring $\mathrm{MAPbI}_{3}$ perovskite and Co- and Ni-incorporated $\mathrm{MAPbI}_{3}$ perovskites. The addition of $\mathrm{CoCl}_{2}$ or $\mathrm{NiCl}_{2}$ to $\mathrm{MAPbI}_{3}$ perovskite decreased the EQE to 400-800 $\mathrm{nm}$. The EQEs of these cells were lower than those of the cells featuring $\mathrm{MAPb}(\mathrm{Co}) \mathrm{I}_{3}{ }^{23}$ and $\mathrm{MAPb}(\mathrm{Ni}) \mathrm{I}_{3}$ perovskite layers. ${ }^{25}$ In this study, the photons did not efficiently convert into current, and $J_{\mathrm{sc}}$ and $\eta$ decreased. Carrier recombination and loss occurred near the interfaces with defects and pinholes in the cubic-phase perovskite layer. $E_{\mathrm{g}}$ was estimated using the alignment of band edges in $\mathrm{EQE}$. The $E_{\mathrm{g}}$ values of $\mathrm{MAPb}(\mathrm{Co}) \mathrm{I}_{3}$ and $\mathrm{MAPb}(\mathrm{Ni}) \mathrm{I}_{3}$ were determined to be 1.547 and $1.545 \mathrm{eV}$, respectively, which were lower than that of the $\mathrm{MAPbI}_{3}$ crystal $\left(1.563 \mathrm{eV}\right.$, Table IV). The $E_{\mathrm{g}}$ values of $\mathrm{MAPb}(\mathrm{Co}) \mathrm{I}_{3}$ and $\mathrm{MAPb}(\mathrm{Ni}) \mathrm{I}_{3}$ were slightly underestimated compared with those of the recently reported cells featuring $\mathrm{MAPb}(\mathrm{Co}) \mathrm{I}_{3}$ or $\mathrm{MAPb}(\mathrm{Ni}) \mathrm{I}_{3}$ crystals (1.56 $\mathrm{eV}^{23}$ and $1.58 \mathrm{eV},{ }^{25}$ respectively). The
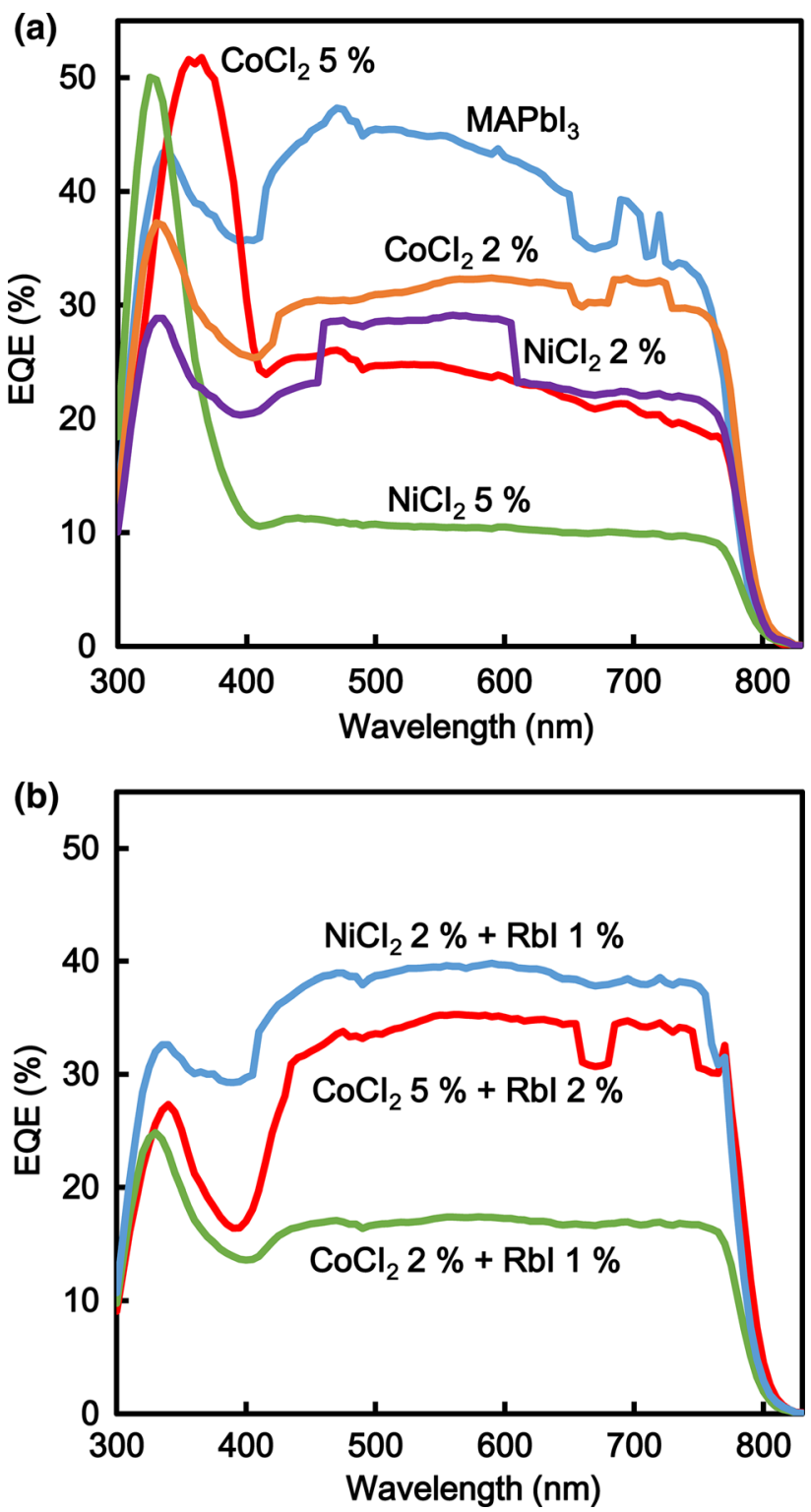

Fig. 3. External quantum efficiency of the perovskite solar cells with (a) $\mathrm{CoCl}_{2}, \mathrm{NiCl}_{2}$, and (b) $\mathrm{Rbl}$.

experimental behavior of the cells was discussed based on the band structure, effective mass, and $E_{\mathrm{g}}$. The addition of $\mathrm{Co}$ or $\mathrm{Ni}$ to the $\mathrm{MAPbI}_{3}$ perovskite 
crystals affected the internal structure, crystal growth, electron structure, and $E_{g}$, which was related to the energy levels of the VB. ${ }^{23}$ The band structure near the VB was attributed to the effect of the Jahn-Teller distortion on energy level splitting, and the hybridization of the $3 d$ orbitals of the transition metal with the $5 p$ orbitals of the $\mathrm{I}^{-}$ions, which served as ligands in the coordination structure.

The changes in $\eta$ and $J_{\mathrm{sc}}$ of perovskite solar cells were analyzed at $27^{\circ} \mathrm{C}$ and $20 \%$ humidity for $50 \mathrm{~d}$, as illustrated in Fig. $4 \mathrm{a}$ and b. The co-addition of $2 \%$ $\mathrm{NiCl}_{2}$ and $1 \% \mathrm{RbI}$ increased $\eta$ and $J_{\mathrm{sc}}$ after $36 \mathrm{~d}$. When $2 \% \mathrm{NiCl}_{2}$ and $1 \% \mathrm{RbI}$ were co-added to $\mathrm{MAPbI}_{3}$ perovskite, $\eta$ and $J_{\mathrm{sc}}$ increased significantly
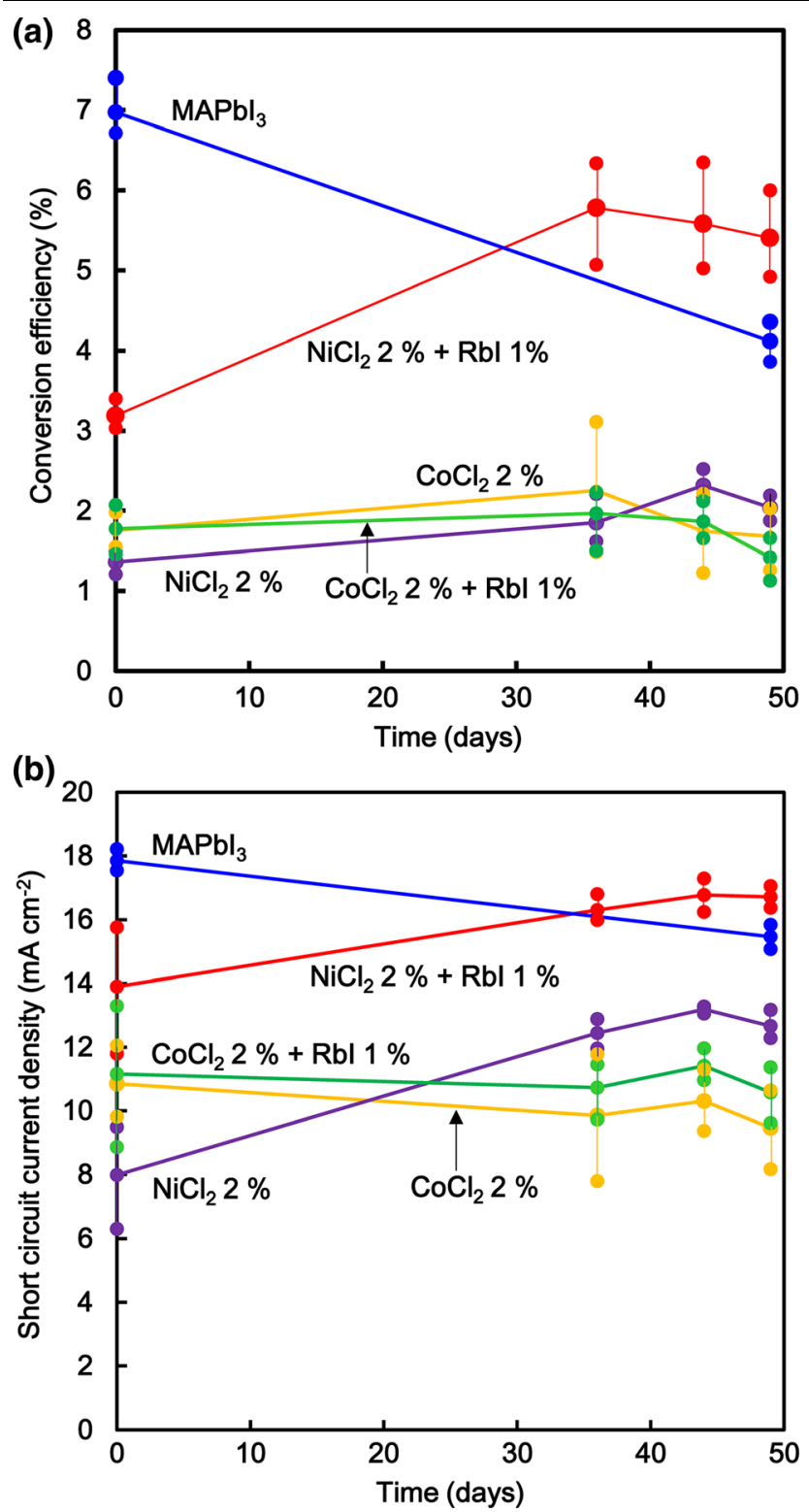

Fig. 4. Long-term stability of (a) conversion efficiencies and (b) short-circuit current densities for the perovskite solar cells. The solar cells were stored and characterized at temperature of $27^{\circ} \mathrm{C}$ and humidity of $20 \%$. The average values of $\eta$ and $J_{\text {SC }}$ were estimated from the three electrodes in the devices. from $3.19 \%$ to $5.78 \%$ and from $13.91 \mathrm{~mA} \mathrm{~cm}^{-2}$ to $16.30 \mathrm{~mA} \mathrm{~cm}{ }^{-2}$, respectively, in $36 \mathrm{~d}$. The increase in $J_{\mathrm{sc}}$ and $\eta$ was attributed to carrier diffusion promotion in the perovskite crystal with the coaddition of $\mathrm{NiCl}_{2}$ and $\mathrm{RbI}$ owing to the solid-phase reaction with diffusion in the perovskite layer compared with the slow deterioration behavior of $\mathrm{MAPb}(\mathrm{Ni}) \mathrm{I}_{3}$ for $150 \mathrm{~h}^{25}$ For the $\mathrm{MAPbI}_{3}$ solar cells, $\eta$ and $J_{\mathrm{sc}}$ suddenly decreased from $6.97 \%$ to $4.12 \%$ and from $17.85 \mathrm{~mA} \mathrm{~cm}^{-2}$ to $15.5 \mathrm{~mA} \mathrm{~cm}^{-2}$, respectively, after 49 days (Fig. $4 \mathrm{~b}$ and c). This reduced performance was ascribed to the decrease in photocurrent with carrier recombination near defects and the interface while causing a decomposition reaction with diffusion of MA cations and halogen anions for the long-term period.

The XRD patterns, crystal sizes, and lattice constants of the solar cells featuring $\mathrm{CoCl}_{2^{-}}, \mathrm{NiCl}_{2^{-}}$ , $\mathrm{CoCl}_{2} / \mathrm{RbI}$-, and $\mathrm{NiCl}_{2} / \mathrm{RbI}$-incorporated $\mathrm{MAPbI}_{3}$ perovskites are presented in Fig. $5 \mathrm{a}$ and $\mathrm{b}$ and Table II. The XRD patterns of the $\mathrm{MAPbI}_{3}$ perovskite crystals were in good agreement with data reported in the literature. ${ }^{30}$ The strong diffraction peak at $2 \theta$ corresponded to the $d$-spacing of $6.271 \AA$, which was assigned to the (100) plane of the cubic perovskite crystals. The intensity of the peak at $2 \theta$ increased with increasing amounts of $\mathrm{CoCl}_{2}$ and $\mathrm{NiCl}_{2}$ (Fig. 5a and b). Table II summarizes the crystallite sizes, lattice constants, crystal systems, and unit cell volume per number of formula units in the cells of $\mathrm{CoCl}_{2^{-}}, \mathrm{NiCl}_{2^{-}}, \mathrm{CoCl}_{2} / \mathrm{RbI}-$, and $\mathrm{NiCl}_{2} /$ RbI-incorporated $\mathrm{MAPbI}_{3}$ perovskite crystals. The crystallite sizes of the $\mathrm{MAPbI}_{3}$ perovskites incorporated with $5 \% \mathrm{CoCl}_{2}$ or $5 \% \mathrm{NiCl}_{2}(954$ and $1079 \AA$, respectively) were larger than that of pristine $\mathrm{MAPbI}_{3}$ perovskite $(644 \AA)$. The lattice constants of the (100) plane of the $\mathrm{MAPbI}_{3}$ perovskites incorporated with $5 \% \mathrm{CoCl}_{2}$ or $5 \% \mathrm{NiCl}_{2}(6.285 \AA$ and $6.273 \AA$, respectively) were larger than that of pristine $\mathrm{MAPbI}_{3}$ perovskite $(6.271 \mathrm{~A})$. Similarly, the co-addition of $2 \% \mathrm{CoCl}_{2}$ and $1 \% \mathrm{RbI}$ or $2 \% \mathrm{NiCl}_{2}$ and $1 \% \mathrm{RbI}$ to $\mathrm{MAPbI}_{3}$ perovskite increased the crystallite size and lattice constant of the (100) plane.

The changes in crystal structure, growth, and phases of the perovskite crystals with the addition of $\mathrm{Co}$ or $\mathrm{Ni}$ in this study were different from those reported in the literature (Table II). ${ }^{23-25}$ When 1.6 and $3.1 \% \mathrm{Co}^{2+}$ ions were added to $\mathrm{MAPbI}_{3}$ perovskite, the as-grown $\mathrm{MAPbCoI}_{3}$ crystals presented a tetragonal phase. ${ }^{23,24}$ When $3 \% \mathrm{NiCl}_{2}$ was added to $\mathrm{MAPbI}_{3}$ perovskite, the as-grown $\mathrm{MAPbNiI}_{3}$ crystals presented a tetragonal phase and high crystallinity. ${ }^{25}$ Annealing confers thermodynamic stability, surface morphology, crystal structure, crystallinity, and phase. In this study, annealing at $140^{\circ} \mathrm{C}$ led to transition into a stable cubic crystal phase. Annealing at temperatures above the phase transition temperature affected crystal growth and the phase related to $J_{\mathrm{sc}}$ and $\eta$.

The unit cell volume per number of formula units slightly increased with increasing the percentages 

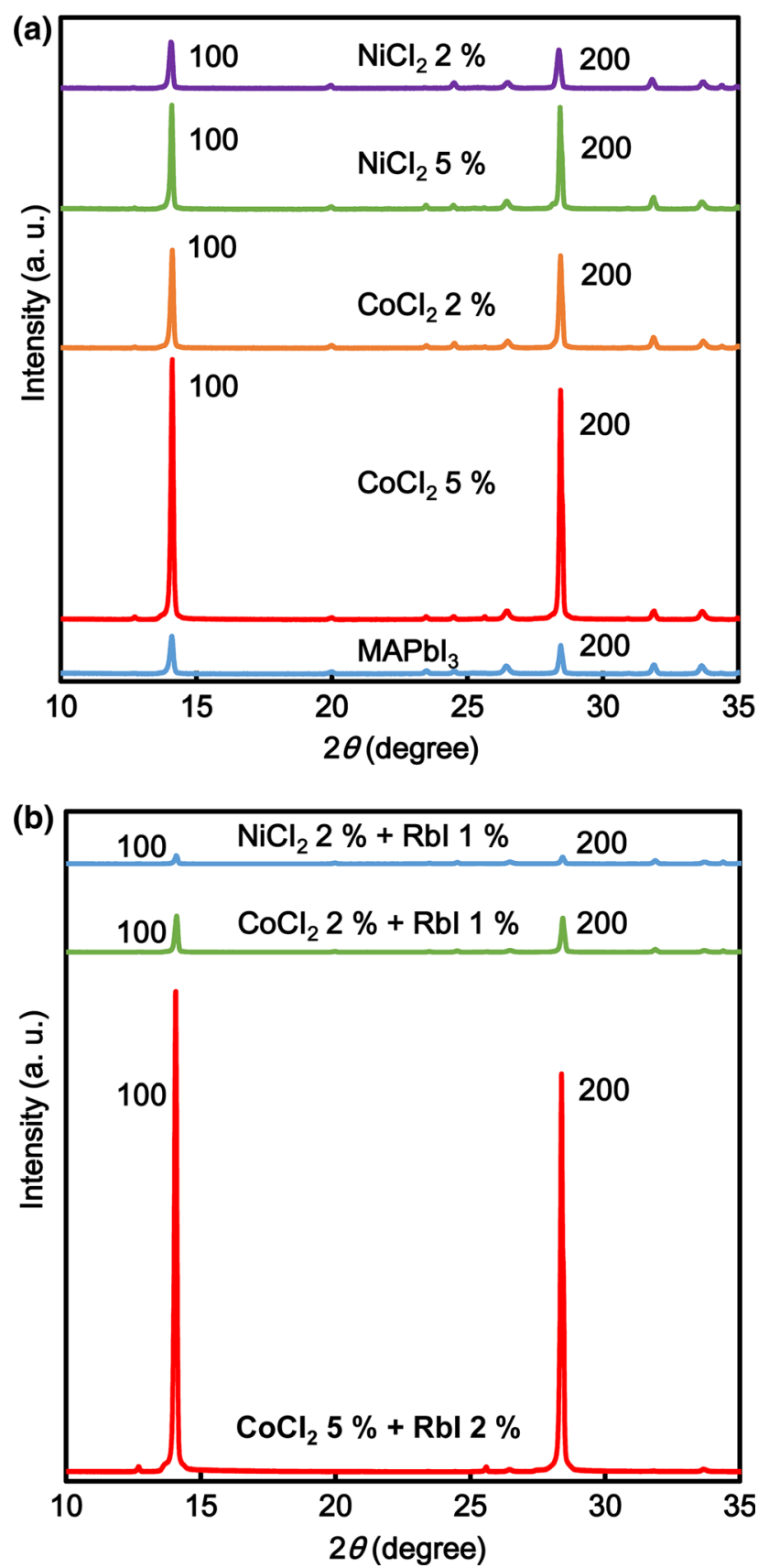

Fig. 5. X-ray diffraction patterns of the perovskite solar cells with (a) $\mathrm{CoCl}_{2}, \mathrm{NiCl}_{2}$, and (b) Rbl.

of $\mathrm{CoCl}_{2}, \mathrm{NiCl}_{2}$, and $\mathrm{RbI}$, even though the ionic radii of $\mathrm{Co}^{2+}$ and $\mathrm{Ni}^{2+}$ ions ( 0.75 and $0.69 \AA$, respectively) are smaller than that of $\mathrm{Pb}^{2+}$ ions $(1.19 \AA)$, and the radius of $R b^{+}$ions $(1.72 \AA)$ is smaller than that of $\mathrm{MA}^{+}$ions $(2.17 \AA)$. The perovskite layer contained numerous defects and voids. The incorporation of small amounts of Co or Ni improved crystal nucleation and growth by suppressing the formation of vacancy defects near grain boundaries and shortrange order of the crystal structure in the perovskite layer; this enhanced the stability and the strength of the chemical bonds between the $\mathrm{Ni}^{2+}$ or $\mathrm{Co}^{2+}$ ions and $\mathrm{I}^{-}$ions in octahedral coordination. ${ }^{24,47}$
The co-addition of small amounts of $\mathrm{CoCl}_{2}$ and $\mathrm{RbI}$ or $\mathrm{NiCl}_{2}$ and $\mathrm{RbI}$ markedly improved crystal orientation and growth and suppressed grain boundaries in the perovskite layer. Rb occupied the MA defects within the perovskite crystals and promoted crystal nucleation and growth in the perovskite layer. ${ }^{16}$ The crystal growth in the perovskite layer reduced the trap density between perovskite grains and increased $J_{\mathrm{sc}}$ and $\eta$. The $\mathrm{Ni} / \mathrm{Rb}$-incorporated $\mathrm{MAPbI}_{3}$ perovskite crystal presented a stable $\eta$.

The optical microscopy images of the solar cells featuring $\mathrm{MAPbI}_{3}$ perovskite, $\mathrm{CoCl}_{2}$-incorporated $\mathrm{MAPbI}_{3}$ perovskites, $\mathrm{NiCl}_{2}$-incorporated $\mathrm{MAPbI}_{3}$ perovskites, $\mathrm{CoCl}_{2} / \mathrm{RbI}$-incorporated $\mathrm{MAPbI}_{3}$ perovskites, and $\mathrm{NiCl}_{2} / \mathrm{RbI}$-incorporated $\mathrm{MAPbI}_{3}$ perovskites are presented in Fig. 6. Uniform and dense crystal films with high surface coverage were obtained when $5 \% \mathrm{CoCl}_{2}$ and $2 \% \mathrm{RbI}$ were co-added to $\mathrm{MAPbI}_{3}$ perovskite. For the $\mathrm{MAPb}_{0.9} \mathrm{Co}_{0.1} \mathrm{I}_{3}$ thin film, the number of voids and defects was low, which promoted crystal nucleation and growth. Surface modification with crystal growth improved the photovoltaic performance of the cells. Surface morphological observation and XRD analysis were performed after long-term cell use. The crystallinity, surface morphology, particle size, and surface coverage of the perovskite-based solar cells after long-term use are presented in Fig. 7a and b. The intensity of the peak ascribed to the (100) crystal plane of the $\mathrm{MAPbI}_{3}$ perovskite crystal coadded with $2 \% \mathrm{NiCl}_{2}$ and $1 \% \mathrm{RbI}$ increased after 44 days of use; moreover, the $I_{100} / I_{210}$ ratio increased from 2.59 to 3.35 . In comparison, the $I_{100} / I_{210}$ ratio of the solar cell featuring $\mathrm{MAPbI}_{3}$ perovskite increased from 4.10 to 4.93 . Typically, a $I_{100} / I_{210}$ ratio of 2.1 corresponds to random crystal orientation. These results indicated that crystals with (100) orientation grew on the perovskite layer after 44 days of use. The co-addition of $2 \% \mathrm{NiCl}_{2}$ and $1 \% \mathrm{RbI}$ to $\mathrm{MAPbI}_{3}$ perovskite promoted particle growth and passivation and suppressed decomposition. The particle size and surface coverage of the $\mathrm{MAPbI}_{3}$ perovskite incorporated with $2 \% \mathrm{NiCl}_{2}$ and $1 \% \mathrm{RbI}$ increased from $14.5 \mu \mathrm{m}$ to $25.1 \mu \mathrm{m}$ and from $70.3 \mu \mathrm{m}$ to $84.7 \mu \mathrm{m}$, respectively, after 60 days of use. Conversely, for the solar cell featuring pristine $\mathrm{MAPbI}_{3}$ perovskite, the particle size and surface coverage decreased from $13.0 \mu \mathrm{m}$ to $3.4 \mu \mathrm{m}$ and from $61.5 \mu \mathrm{m}$ to $48.2 \mu \mathrm{m}$, respectively. These results indicated the suppression of crystal nucleation and growth with decreasing particle size. The changes in crystalline surface morphology and crystal growth after long-term aging are illustrated in Fig. 8. The co-addition of $\mathrm{NiCl}_{2}$ and $\mathrm{RbI}$ to $\mathrm{MAPbI}_{3}$ perovskite improved the growth of crystals with (100) orientation. The promotion of crystal growth and orientation without defects and pinholes improved the long-term stability of the photovoltaic cells and suppressed the decomposition reaction and ion diffusion (Table III). 
Table II. Crystallite sizes and lattice constants of the perovskite crystals

\begin{tabular}{|c|c|c|c|c|c|}
\hline Perovskite & $\begin{array}{l}\text { Crystallite } \\
\text { size (A) }\end{array}$ & $\begin{array}{l}\text { Lattice con- } \\
\text { stant }(\AA)\end{array}$ & Ref. & $\begin{array}{c}\text { Crystal system (space } \\
\text { group) }\end{array}$ & $\begin{array}{c}\text { Unit cell volume } \\
\left(\AA^{\mathbf{3}}\right) / Z^{* * *}\end{array}$ \\
\hline $\mathrm{MAPbI}_{3}$ & 644 & $\begin{array}{c}6.271(2) \\
6.2842(1)^{*}\end{array}$ & $\begin{array}{l}\text { Present } \\
\text { work } \\
23\end{array}$ & $\begin{array}{l}\text { Cubic } \\
(P m \overline{3} m)\end{array}$ & $\begin{array}{l}246.63 \\
248.72^{*}\end{array}$ \\
\hline \multicolumn{6}{|l|}{ Additives } \\
\hline $\mathrm{CoI}_{2} 1.6 \% *$ & & $\begin{array}{c}a=8.88457(1)^{*} \\
c=12.6034(5)\end{array}$ & 23 & Tetragonal $(I 4 / \mathrm{mcm})$ & $248.72^{*}$ \\
\hline $\mathrm{CoCl}_{2} 2 \%$ & 814 & 6.272 & $\begin{array}{l}\text { Present } \\
\text { work }\end{array}$ & $\begin{array}{c}\text { Cubic } \\
(P m \overline{3} m)\end{array}$ & 246.73 \\
\hline $\mathrm{CoI}_{2} 3.1 \% *$ & & $\begin{array}{c}a=8.88624(5)^{*} \\
c=12.6134(0)\end{array}$ & & Tetragonal $(\mathrm{I} 4 / \mathrm{mcm})$ & $249.01^{*}$ \\
\hline $\mathrm{CoCl}_{2} 5 \%$ & 955 & 6.285 & $\begin{array}{c}\text { Present } \\
\text { work }\end{array}$ & $\begin{array}{l}\text { Cubic } \\
(P m \overline{3} m)\end{array}$ & 248.27 \\
\hline $\mathrm{NiCl}_{2} 2 \%$ & 608 & $6.285(1)$ & $\begin{array}{l}\text { Present } \\
\text { work }\end{array}$ & $\begin{array}{l}\text { Cubic } \\
(P m \overline{3} m)\end{array}$ & 248.28 \\
\hline $\mathrm{NiCl}_{2} 3 \% * *$ & & $\begin{array}{c}\mathrm{a}=8.8758^{* *} \\
\mathrm{c}=12.6283\end{array}$ & 25 & $\begin{array}{l}\text { Tetragonal } \\
\quad(I 4 / \mathrm{m})\end{array}$ & $248.72 * *$ \\
\hline $\mathrm{NiCl}_{2} 5 \%$ & 1079 & $6.273(1)$ & $\begin{array}{l}\text { Present } \\
\text { work }\end{array}$ & $\begin{array}{l}\text { Cubic } \\
(P m \overline{3} m)\end{array}$ & 246.86 \\
\hline $\begin{array}{l}\mathrm{CoCl}_{2} \\
2 \%+\mathrm{RbI} 1 \%\end{array}$ & 729 & 6.274 & $\begin{array}{c}\text { Present } \\
\text { work }\end{array}$ & $\begin{array}{l}\text { Cubic } \\
(P m \overline{3} m)\end{array}$ & 246.96 \\
\hline $\begin{array}{l}\mathrm{NiCl}_{2} \\
2 \%+\mathrm{RbI} 1 \%\end{array}$ & 771 & 6.275 & $\begin{array}{c}\text { Present } \\
\text { work }\end{array}$ & $\begin{array}{l}\text { Cubic } \\
(P m \overline{3} m)\end{array}$ & 247.08 \\
\hline $\begin{array}{l}\mathrm{CoCl}_{2} \\
5 \%+\mathrm{RbI} 2 \%\end{array}$ & 1239 & $6.284(2)$ & $\begin{array}{c}\text { Present } \\
\text { work }\end{array}$ & $\begin{array}{l}\text { Cubic } \\
(\operatorname{Pm} \overline{3} m)\end{array}$ & 248.17 \\
\hline
\end{tabular}

$*$ Ref. $23, * *$ Ref. 25 .

$* * * Z$ is the number of formula units in a unit cell.

The band structures near the $\mathrm{VB}$ and $\mathrm{CB}$ of the $\mathrm{MAPbI}_{3}, \mathrm{MAPb}(\mathrm{Co}) \mathrm{I}_{3}$, and $\mathrm{MAPb}(\mathrm{Ni}) \mathrm{I}_{3}$ perovskite crystals are presented in Fig. 9. The band dispersions and band gaps of the Brillouin zone of the perovskite crystal lattice along the direction of the wave vector were analyzed. The band along of the $\Gamma$ $(0,0,0)$ direction in the $\mathrm{MAPb}(\mathrm{Ni}) \mathrm{I}_{3}$ perovskite crystal presented a strong dispersion similar to that of the $R(1 / 2,1 / 2,1 / 2)$ direction in the $\mathrm{MAPbI}_{3}$ perovskite crystal (Fig. 9). The band of the MAPb(Co) $\mathrm{I}_{3}$ perovskite crystal was widely dispersed along the direction. The partial replacement of $\mathrm{Pb}$ in the perovskite crystal with $\mathrm{Co}$ or $\mathrm{Ni}$ affected the energy dispersion near the VB and CB by narrowing the band gap. The $m_{\mathrm{e}}{ }^{*} / m_{\mathrm{o}}$ and $m_{\mathrm{h}}{ }^{*} / m_{\mathrm{o}}$ values are listed in Table IV. The $m_{\mathrm{e}} / \mathrm{m}_{\mathrm{o}}$ values of all analyzed systems presented the same order of magnitude. The calculated values revealed the same electron diffusion tendency related to mobility in the cubic phase. The $m_{\mathrm{h}}{ }^{*} / m_{\mathrm{o}}$ values of the $\mathrm{MAPb}(\mathrm{Ni}) \mathrm{I}_{3}$ and $\mathrm{MAPb}(\mathrm{Co}) \mathrm{I}_{3}$ perovskite crystals were estimated to be 0.05 and 0.72 , respectively, which were comparable with that of the $\mathrm{MAPbI}_{3}$ perovskite crystal (0.02). Carrier diffusion related to hole mobility was inversely proportional with $\mathrm{m}^{*}$ for the $\mathrm{MAPb}(\mathrm{Ni}) \mathrm{I}_{3}$ perovskite crystal and was higher than that of the $\mathrm{MAPb}(\mathrm{Co}) \mathrm{I}_{3}$ perovskite crystal. This indicated that the $\mathrm{MAPb}(\mathrm{Ni}) \mathrm{I}_{3}$ perovskite crystal could promote photoinduced carrier diffusion, which led to an increase in charge carrier mobility and $J_{\mathrm{sc}}$ and a decrease in $R_{\mathrm{s}}$. The calculated and experimental $E_{\mathrm{g}}$ values for the $\mathrm{MAPbI}_{3}, \mathrm{MAPb}(\mathrm{Co}) \mathrm{I}_{3}$, and $\mathrm{MAPb}(-$ $\mathrm{Ni} \mathrm{I}_{3}$ perovskite crystals are listed in Table IV. The experimental $E_{\mathrm{g}}$ values were confirmed by the alignment of the band edges in EQE. The theoretical and experimental $E_{\mathrm{g}}$ values of the perovskite crystals were similar. The ab initio quantum calculation EQE results using the GGA-PBE exchange-correlation function were lower than the experimental EQE values. These results indicated that $E_{\mathrm{g}}$ was affected by the crystal structure and phase. ${ }^{23,25}$

The PDOS including occupancies, energy levels of the $2 p$ and $3 d$ orbitals of $\mathrm{I}, \mathrm{N}, \mathrm{Pb}, \mathrm{Co}$, and $\mathrm{Ni}$ near the VB and $\mathrm{CB}$ of the $\mathrm{MAPbI}_{3}, \mathrm{MAPb}(\mathrm{Ni}) \mathrm{I}_{3}$, and $\mathrm{MAPb}(\mathrm{Co}) \mathrm{I}_{3}$ perovskite crystals were analyzed, and the results are presented in Fig. 10a, b, and c. The $2 p$ orbitals of the I atom and $2 p$ orbitals of the $\mathrm{Pb}$ atoms were located near the VB and CB levels of the reference $\mathrm{MAPbI}_{3}$ perovskite crystal. For the $\mathrm{MAPb}(\mathrm{Ni}) \mathrm{I}_{3}$ perovskite crystal, the $3 d$ orbitals of the $\mathrm{Ni}$ atoms were partially hybridized with the $2 p$ orbitals of the I atoms near the VB levels. The ligand-to-metal charge transfer promoted photoinduced carrier generation. The holes easily diffused 

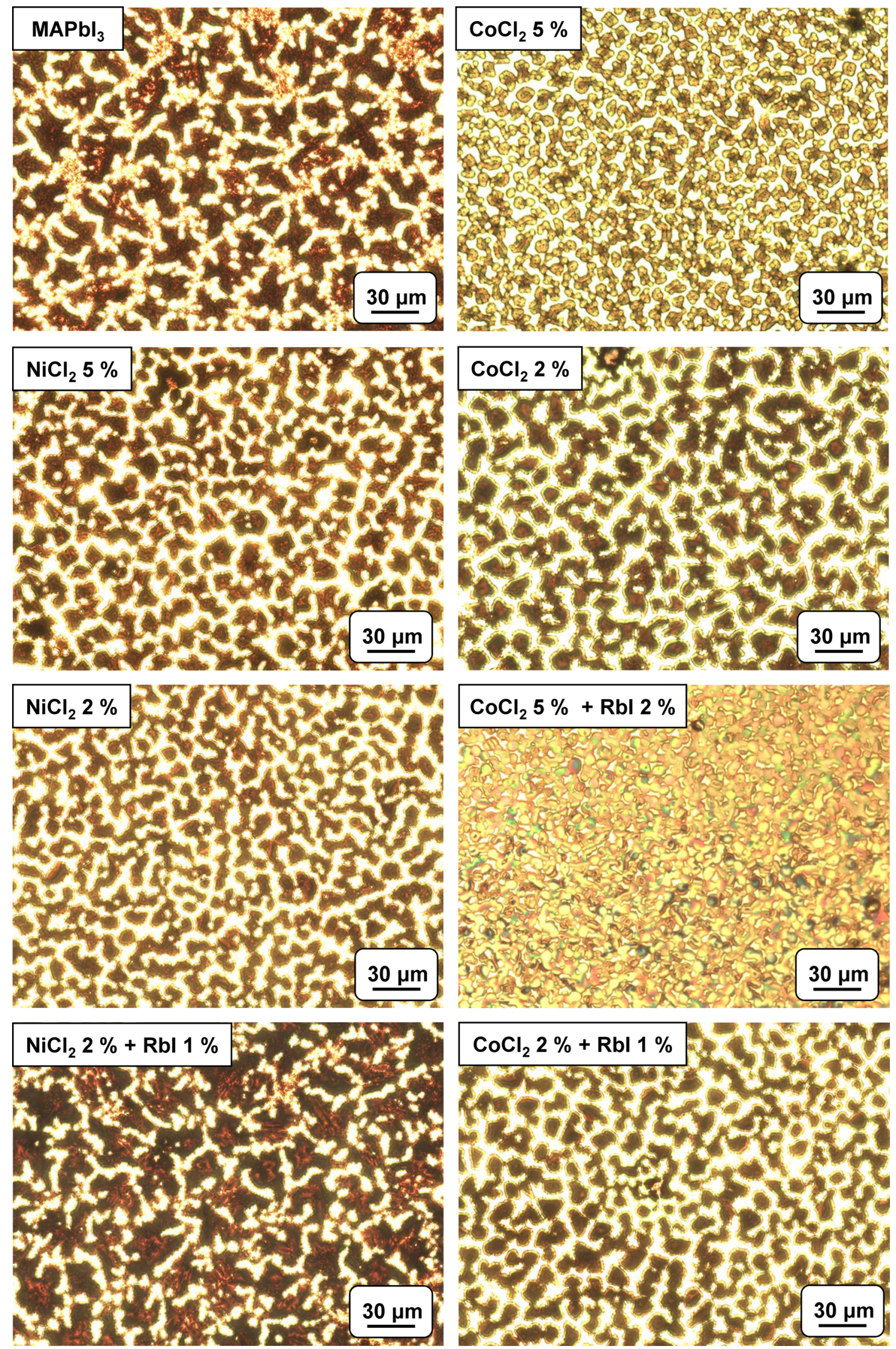

Fig. 6. Optical microscope images of the perovskite crystals with $\mathrm{CoCl}_{2}, \mathrm{NiCl}_{2}$, and $\mathrm{Rbl}$. 


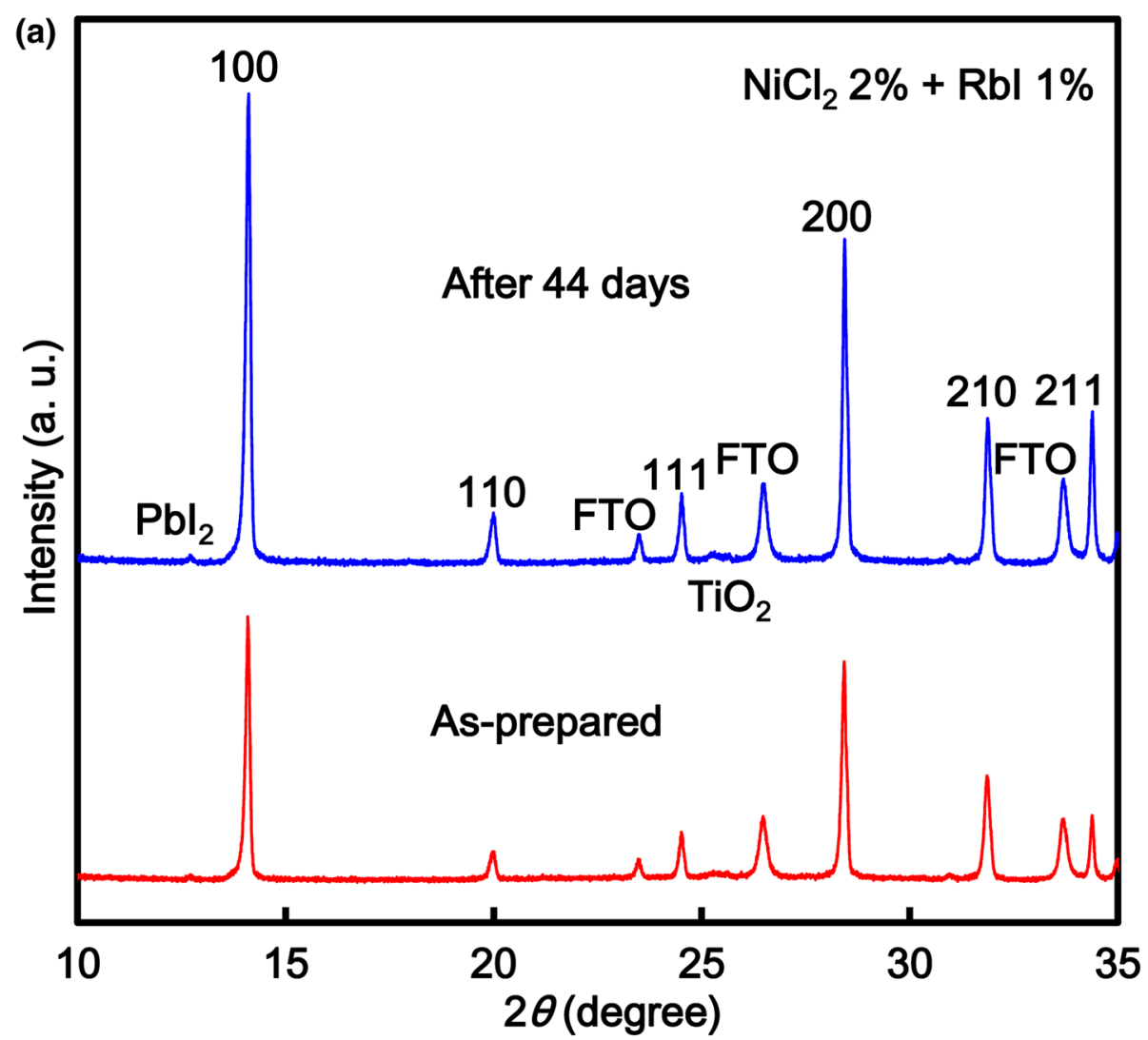

(b)
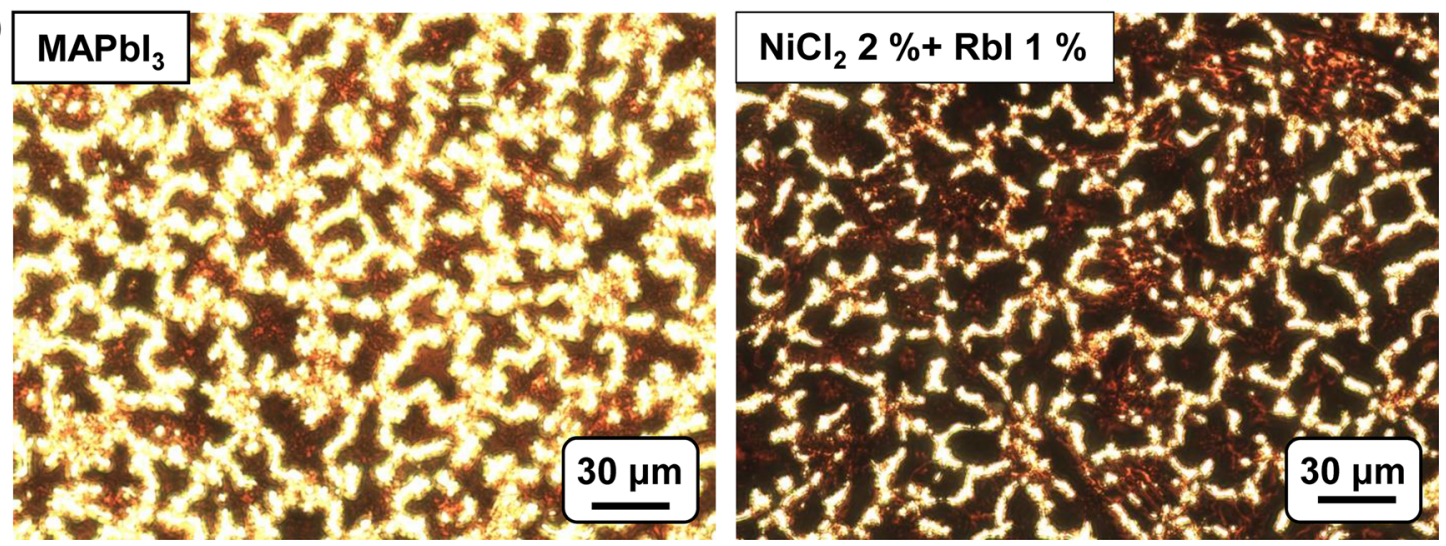

Fig. 7. (a) X-ray diffraction patterns of the $\mathrm{MAPbl}_{3}$ perovskite solar cells with $\mathrm{NiCl}_{2}$ and $\mathrm{Rbl}$ after 44 days and (b) optical microscope images after 60 days. The samples were stored and characterized at temperature of $27^{\circ} \mathrm{C}$ and humidity of $20 \%$.

around the VB, which suggested that hole mobility, which was related to $J_{\mathrm{sc}}$ and $\eta$, improved. For the $\mathrm{MAPb}(\mathrm{Co}) \mathrm{I}_{3}$ perovskite crystals, the $3 d$ orbitals of Co with strong PDOS were localized above the VB. The $2 p$ orbitals of the I atoms were slightly shifted near the VB and presented a wide energy dispersion, which caused an increase in the efficiency mass related to carrier mobility. The ligand-tometal charge transfer was not caused by the localization of the $3 d$ orbitals of Co atoms. For the $\mathrm{MAPb}_{0.9} \mathrm{Co}_{0.1} \mathrm{I}_{3}$ crystal, the contribution of the $3 d$ orbitals of the Co atoms near the VB promoted charge transfer, resulting in enhanced hole mobility. ${ }^{24}$ In this study, electrons and holes were not generated and did not diffuse near the $C B$ and VB. The wide dispersion of the band structure was responsible for the decrease in $\eta$ and $J_{\mathrm{sc}}$ with diffusion suppression in the perovskite crystal.

The calculated IR and Raman vibration modes of the $\mathrm{MAPb}(\mathrm{Ni}) \mathrm{I}_{3}$ and $\mathrm{MAPbI}_{3}$ perovskite crystals are illustrated in Fig. 11a, b, c, and d. The IR and Raman vibration modes in the wide wavenumber range of $1000-4000 \mathrm{~cm}^{-1}$ were assigned to the bending modes of the $\mathrm{N}-\mathrm{C}$ and $\mathrm{N}-\mathrm{H}$ bonds of MA. The high intensity of the vibration modes in the IR and Raman spectra was ascribed to stretching of the 

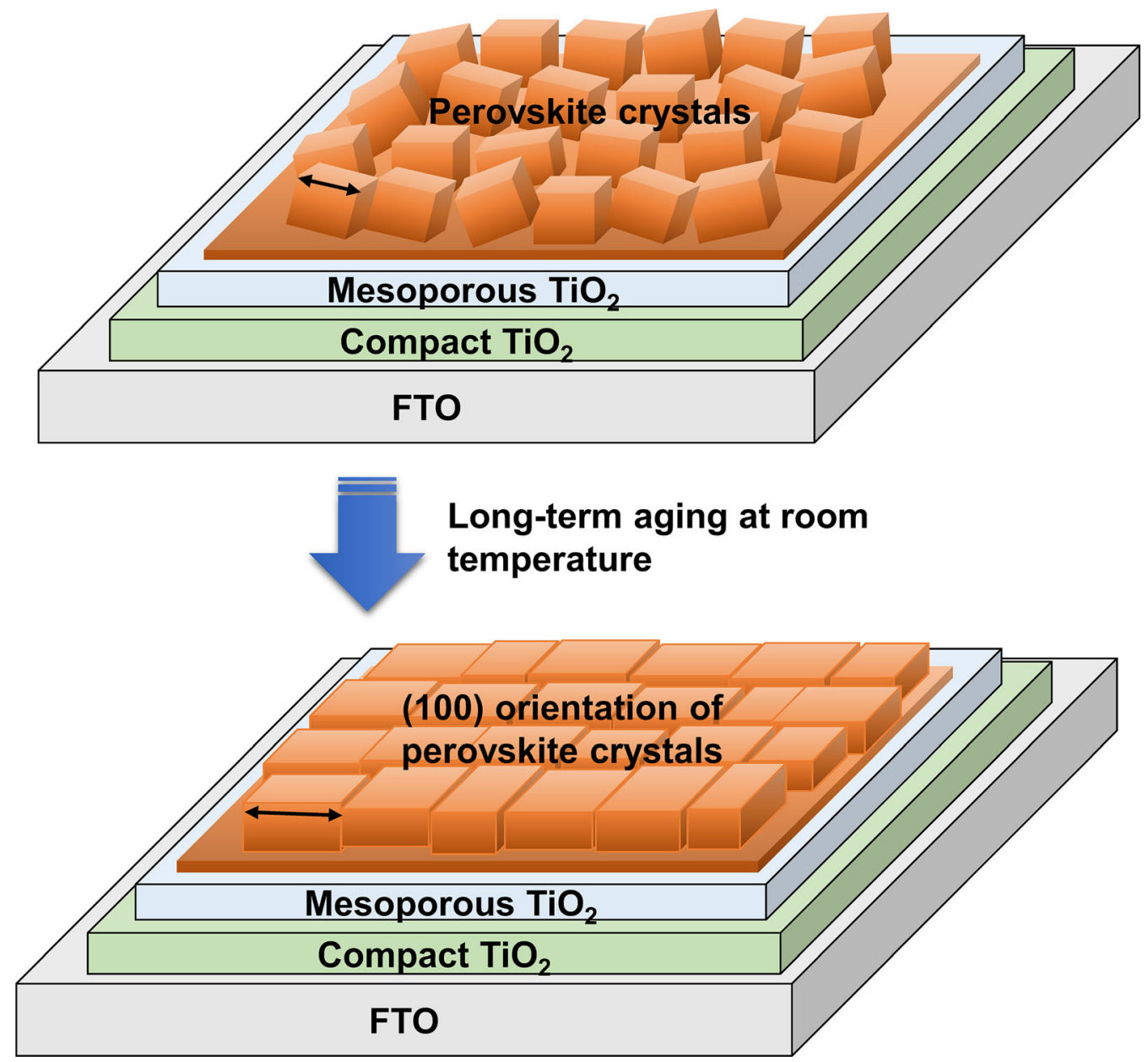

Fig. 8. Change in the surface morphology and crystal growth after long-term aging.

Table III. Changes in the particle sizes and surface coverages on the perovskite layer after 60 days

\begin{tabular}{|c|c|c|c|c|}
\hline \multirow[b]{2}{*}{ Devices } & \multicolumn{2}{|c|}{ Particle size $(\mu \mathrm{m})$} & \multicolumn{2}{|c|}{ Surface coverage $(\%)$} \\
\hline & As-prepared & After 60 days & As-prepared & After 60 days \\
\hline $\mathrm{MAPbI}_{3}$ & 13.0 & 3.4 & 61.5 & 48.2 \\
\hline $\mathrm{NiCl}_{2} 2 \%+\mathrm{RbI} 1 \%$ & 14.5 & 25.1 & 70.3 & 84.7 \\
\hline
\end{tabular}

$\mathrm{Pb}-\mathrm{I}$ bonds in the narrow wavenumber range of $20-$ $200 \mathrm{~cm}^{-1}$. The calculated IR and Raman vibration modes of the $\mathrm{MAPbI}_{3}$ perovskite crystal were similar to the experimental data. ${ }^{28,34-36}$ The IR and Raman vibration modes of the $\mathrm{MAPb}(\mathrm{Ni}) \mathrm{I}_{3}$ crystal were attributed to the asymmetric stretching of the $\mathrm{Ni}-\mathrm{I}$ bonds in the coordination structure. ${ }^{25}$ The stretching modes of $\mathrm{MAPb}(\mathrm{Ni}) \mathrm{I}_{3}$ were downshifted compared with those of the reference $\mathrm{MAPbI}_{3}$ perovskite crystal. The strength of the IR vibration modes was slightly lower and wider at the low wavenumber of $150 \mathrm{~cm}^{-1}$. The IR vibration modes were attributed to the change in dipole moment associated with changes in vibration and bending. The Raman vibration modes were remarkably higher and wider at the wavenumbers of 60,100 , and $150 \mathrm{~cm}^{-1}$. The Raman stretching vibration mode of the $\mathrm{Pb}-\mathrm{I}$ bonds was associated with changes 
Fabrication and Characterization of Ni-, Co-, and Rb-Incorporated $\mathrm{CH}_{3} \mathrm{NH}_{3} \mathrm{PbI}_{3}$ Perovskite
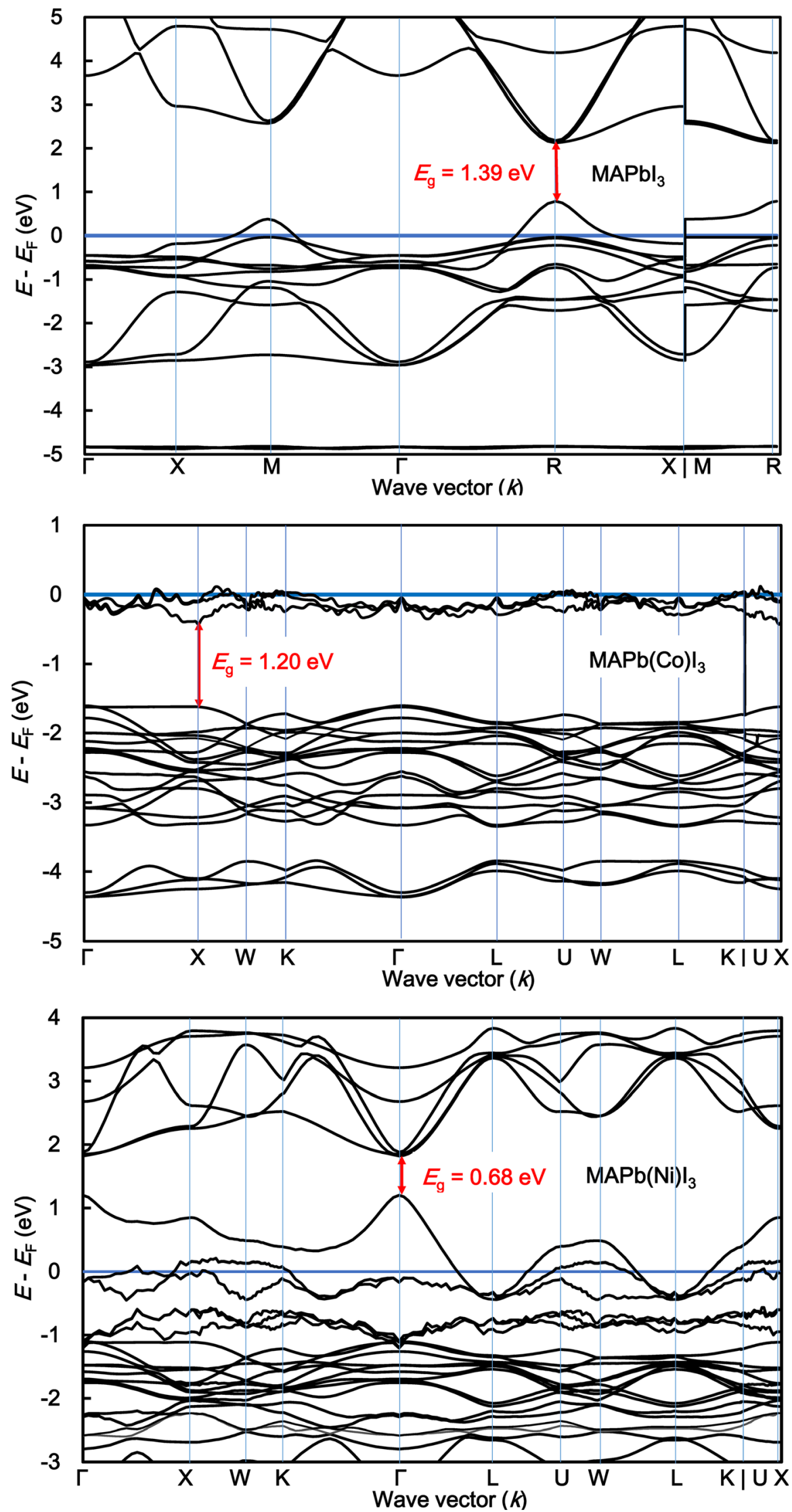

Fig. 9. Calculated band structures of the perovskite crystals. 
Table IV. Effective mass ratios of electrons and holes, $m^{*}{ }_{\mathrm{e}} / \mathrm{m}_{0}$ and $\boldsymbol{m}_{\mathrm{h}}{ }_{\mathrm{h}} / \boldsymbol{m}_{0}$, related to the electron mass $\boldsymbol{m}_{0}$ and band gap energies of the perovskite crystals

\begin{tabular}{|c|c|c|c|c|c|}
\hline \multirow[b]{2}{*}{ Devices } & \multicolumn{2}{|c|}{ Effective mass ratio $\left(m^{*} / m_{o}\right)$} & \multicolumn{3}{|c|}{ Band gap $\left(E_{\mathbf{g}}\right)$} \\
\hline & $m_{e}^{*} / m_{0}$ & $m_{h}^{*} / m_{0}$ & Cal. (eV) & Exp. (eV) & Ref. (eV) \\
\hline $\mathrm{MAPbI}_{3}$ & 0.01 & 0.02 & 1.394 & 1.563 & $1.56^{*}$ \\
\hline $\mathrm{MAPb}(\mathrm{Co}) \mathrm{I}_{3}$ & 0.04 & 0.72 & 1.198 & 1.547 & $1.56^{*}$ \\
\hline $\mathrm{MAPb}(\mathrm{Ni}) \mathrm{I}_{3}$ & 0.05 & 0.05 & 0.697 & 1.545 & $1.64 * *$ \\
\hline
\end{tabular}

in the polarization and distortion of the coordination structure near the ligand field. The vibration mode was similar to those of $\mathrm{Cu}$ - or $\mathrm{Cr}$-incorporated $\mathrm{FAPbI}_{3}$ perovskite crystals. $^{28}$ This vibrational behavior was related to the thermodynamic behavior based on electron-lattice interaction as a phonon effect. The electron-lattice interactions affected carrier diffusion related to carrier mobility. Details on the phonon effect in perovskite crystal can be found from the phonon dispersion. The decomposition was analyzed based on the experimental IR and Raman stretching vibration modes of the $\mathrm{Pb}-\mathrm{I}$ and $\mathrm{N}-\mathrm{H}$ bonds.

The thermodynamic parameters of the metalincorporated $\mathrm{MAPbI}_{3}$ perovskite cubic crystals with $2 \times 2 \times 2$ supercells used as cluster models were estimated using thermodynamic calculations. The $\Delta \mathrm{G}, \Delta \mathrm{H}$, and $\Delta \mathrm{S}$ values of the $\mathrm{MAPbI}_{3}, \mathrm{MAPb}(\mathrm{Ni}) \mathrm{I}_{3}$, and $\mathrm{MA}(\mathrm{Rb}) \mathrm{Pb}(\mathrm{Ni}) \mathrm{I}_{3}$ crystals are listed in Table $\mathrm{V}$. The $\Delta \mathrm{G}$ values of the $\mathrm{MAPb}(\mathrm{Ni}) \mathrm{I}_{3}$ and $\mathrm{MA}(\mathrm{Rb}) \mathrm{Pb}(-$ $\mathrm{Ni}) \mathrm{I}_{3}$ crystals were lower than that of the reference $\mathrm{MAPbI}_{3}$ crystal. The thermodynamic stability of the perovskite crystals was improved by the addition of $\mathrm{Ni}$ and $\mathrm{Rb}$ to $\mathrm{MAPbI}_{3}$. The theoretical results of the cluster models were qualitatively considered, as compared with the reported data. ${ }^{4-50}$ The thermodynamic stability of the perovskite crystals depended on the lattice unit volume per the number of formula units in the unit cell of the perovskite crystal. The lattice energy, $\Delta \mathrm{G}, \Delta \mathrm{H}$, and $\Delta \mathrm{S}$ values were determined as the differences between the corresponding values of the reactants and products for each reaction. For the metal-added perovskites, the reaction processes and paths under actual conditions were not confirmed using the thermal properties and transient measurements using experimental data. It is difficult to quantitatively compare the theoretical and experimental results. The contribution of $\Delta \mathrm{G}$ was dominated by an increase in $\Delta \mathrm{S}$. For the Ni-incorporated $\mathrm{MAPbI}_{3}$ perovskite crystals, $\Delta \mathrm{S}$ depended on the electronlattice interactions as a phonon effect related to the stretching mode of the Ni-I bonds in the low wavenumber range. The electron-lattice interactions suppressed carrier diffusion related to the decrease in carrier mobility and, consequently, $J_{\mathrm{sc}}$ and $\eta$ decreased. The photovoltaic and optical properties of the $\mathrm{MAPb}(\mathrm{Ni}) \mathrm{I}_{3}$ and $\mathrm{MA}(\mathrm{Rb}) \mathrm{Pb}(\mathrm{Ni}) \mathrm{I}_{3}$ perovskite crystals were associated with the electronic correlation while suppressing the electronlattice interaction as the phonon effect in the perovskite uniform layer with high orientation and crystal growth. Therefore, the incorporation of $\mathrm{Ni}$ and $\mathrm{Rb}$ into the $\mathrm{MAPbI}_{3}$ perovskite crystals improved the crystallinity of the perovskite layer and slightly perturbed the coordination structure to optimize the electronic correlation, electron-lattice interactions, thermodynamic behavior, and stability of the perovskite. Controlling the electronic correlation by promoting the growth of defect-free crystals is important for improving the long-term stability of photovoltaic cells.

The long-term photovoltaic performance of the solar cells featuring $\mathrm{MA}(\mathrm{Rb}) \mathrm{Pb}(\mathrm{Ni}) \mathrm{I}_{3}, \mathrm{MAPb}(\mathrm{Ni}) \mathrm{I}_{3}$, and $\mathrm{MAPb}(\mathrm{Co}) \mathrm{I}_{3}$ perovskite crystals was investigated and was compared with the previously reported results for solar cells featuring $\mathrm{MAPb}(\mathrm{Ni}) \mathrm{I}_{3}$ and $\mathrm{MAPb}(\mathrm{Co}) \mathrm{I}_{3}$ perovskite crystals. ${ }^{23-26}$ The photovoltaic solar cell featuring $\mathrm{MA}(\mathrm{Rb}) \mathrm{Pb}(\mathrm{Ni}) \mathrm{I}_{3}$ perovskite crystals could achieve long-term stability by suppressing decomposition. In particular, partially replacing $\mathrm{Pb}^{2+}$ ions with $\mathrm{Ni}^{2+}$ ions and $\mathrm{MA}^{+}$ions with $\mathrm{Rb}^{+}$ions improved long-term stability and carrier mobility based on the effective mass in the crystal structure. However, the initial performance of these cells should be improved to promote their practical applications for photovoltaic devices. The photovoltaic performance of solar cells was assessed 

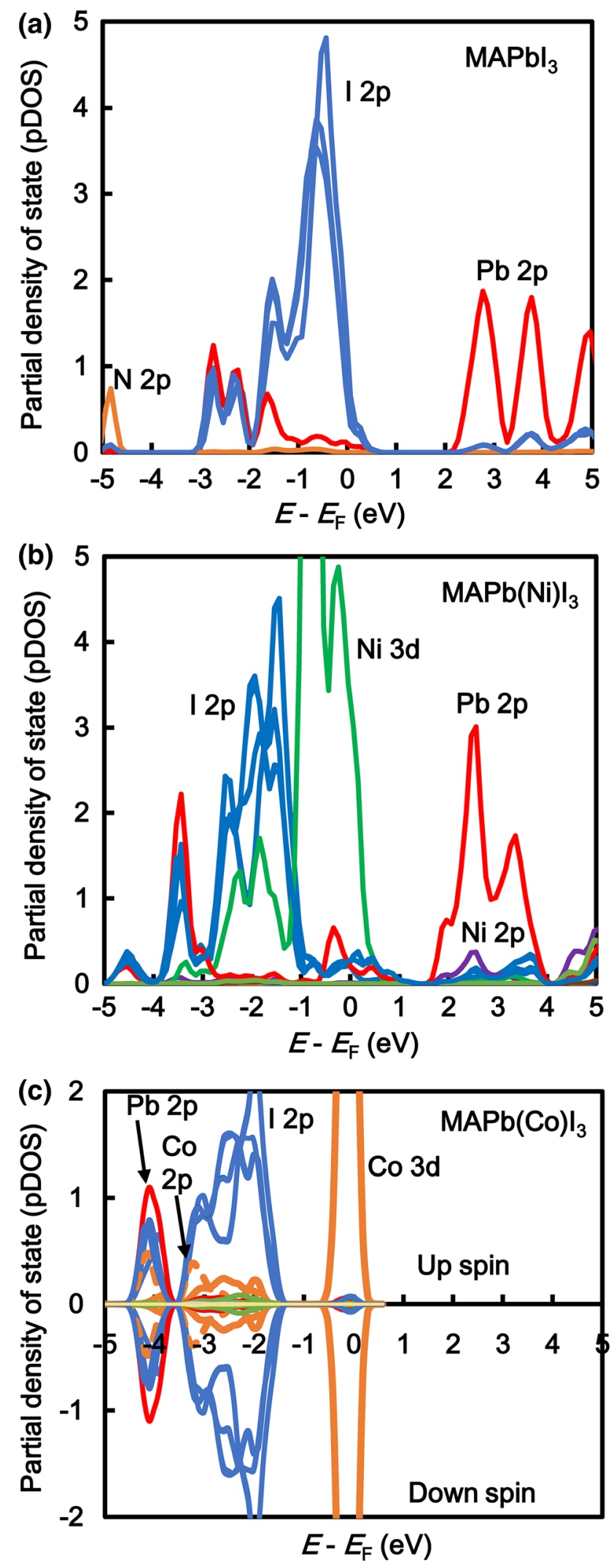

Fig. 10. Partial density of states of (a) $\mathrm{MAPbl}_{3}$, (b) $\mathrm{MAPb}(\mathrm{Ni}) \mathrm{I}_{3}$, and (c) $\mathrm{MAPb}(\mathrm{Co}) \mathrm{I}_{3}$ perovskite crystals. based on the surface modification and coverage, crystal growth, and high (100) orientation in the perovskite layer. Compared to the surface conditions and crystal structures of the previously reported solar cells featuring alkali metals, ${ }^{23-26}$ the crystal nucleation and growth of the $\mathrm{MA}(\mathrm{Rb}) \mathrm{Pb}(\mathrm{Ni}) \mathrm{I}_{3}$ crystals should be promoted and the occurrence of defects and pinholes should be suppressed. The highly accurate optimization of the film formation conditions and crystal nucleation and growth can confer long-term stability to photovoltaic cells, which would increase their potential for practical applications.

\section{CONCLUSIONS}

$\mathrm{Ni}$ - and Co-incorporated $\mathrm{MAPbI}_{3}$ perovskite solar cells were fabricated and characterized, and their photovoltaic properties, crystal growth, and orientation were improved. The partial replacement of $\mathrm{Pb}^{2+}$ ions in the perovskite crystals with $\mathrm{Ni}^{2+}$ or $\mathrm{Co}^{2+}$ ions affected the photoinduced carrier generation and diffusion, effective mass, and metal-toligand charge transfer via hybridization between the $2 p$ orbitals of I and the $3 d$ orbitals of $\mathrm{Ni}$ near the $\mathrm{VB}$. Additionally, the co-addition of $\mathrm{Ni}$ and $\mathrm{Rb}$ to $\mathrm{MAPbI}_{3}$ perovskite crystals improved the long-term stability of the photovoltaic cells owing to crystal growth promotion and surface modification of the perovskite layer. The photovoltaic performance of the solar cells strongly depended on the (100) plane orientation, crystal growth, and surface coverage of the perovskite layer. $J_{\mathrm{sc}}$ and $\eta$ were increased by promoting photoinduced carrier diffusion related to carrier mobility in inverse proportion with $\mathrm{m}^{*} / \mathrm{m}_{0}$ in the band dispersion. The promotion of carrier mobility associated with $m_{\mathrm{h}}{ }^{*} / m_{0}$ was ascribed to the metal-to-ligand charge transfer, which occurred via the hybridization of the $3 d$ orbitals of $\mathrm{Ni}$ with the $2 p$ orbitals of I near the VB. The $\Delta \mathrm{G}$ values indicated the thermodynamic stability of the perovskite crystals co-added with $\mathrm{Ni}$ and $\mathrm{Rb}$. The changes in $\Delta \mathrm{S}$ were attributed to the electronlattice interaction owing to the phonon effect. Photovoltaic mechanisms were associated with the competition between the electron correlation based on the metal-to-ligand charge transfer, electronlattice interaction as a phonon effect, and thermodynamic stability. The electronic correlation was derived from the charge transfer and exchange interactions between the localized $3 d$ orbitals of $\mathrm{Ni}$ and the $2 p$ orbitals of $\mathrm{I}^{-}$ion ligands in the coordination structure. The co-addition of $\mathrm{Ni}$ and $\mathrm{Rb}$ to the perovskite crystals improved the long-term stability of photovoltaic cells. The long-term stability was attributed to the promotion of crystal growth and orientation and the surface modification of the perovskite layer. 

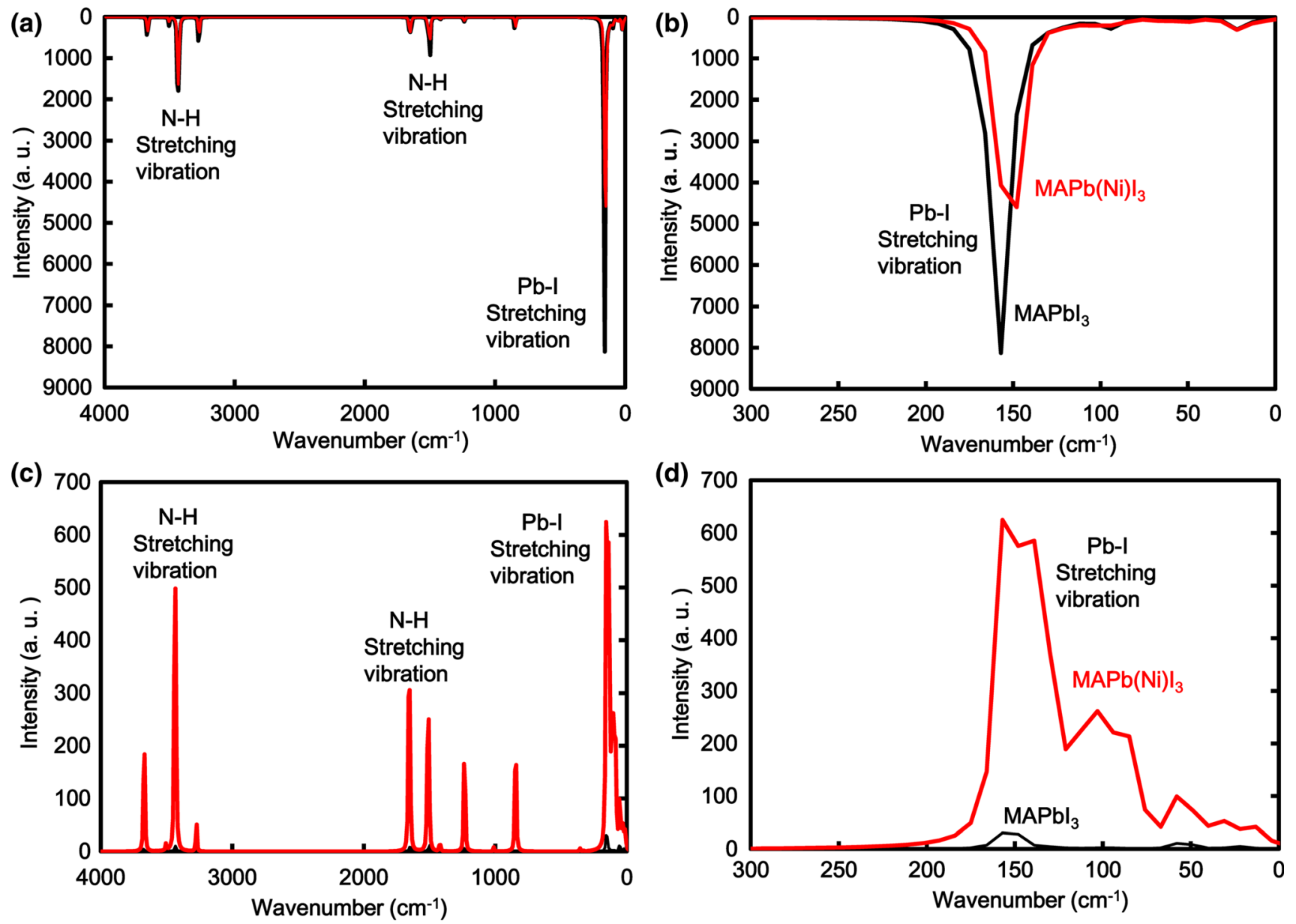

Fig. 11. Calculated vibration modes in (a), (b) IR and (c), (d) Raman spectra of the MAPb(Ni) $I_{3}$ and $\mathrm{MAPbl}_{3}$ crystals in the normal (a) and (c), and (b), (d) enlarged view (a) and (c).

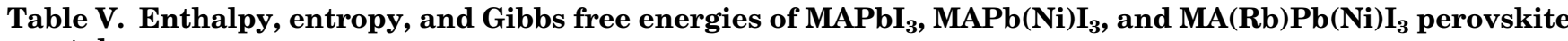
crystals

\begin{tabular}{|c|c|c|c|}
\hline Device & $\mathbf{M A P b I}_{3}$ & $\mathbf{M A P b}(\mathbf{N i}) \mathbf{I}_{3}$ & $\mathbf{M A}(\mathbf{R b}) \mathbf{P b}(\mathbf{N i}) \mathbf{I}_{3}$ \\
\hline Entropy $S\left(\mathrm{~J} \mathrm{~K}^{-1} \mathrm{~mol}^{-1}\right)$ & 4219 & 4318 & 4308 \\
\hline
\end{tabular}

\section{CONFLICT OF INTEREST}

The authors declare that they have no conflict of interest.

\section{REFERENCES}

1. N.J. Jeon, J.H. Noh, W.S. Yang, Y.C. Kim, S. Ryu, J. Seo, and SIl. Seok, Nature, 2015, 517, p 476.

2. M. Saliba, T. Matsu, J.Y. Seo, K. Domanski, J.P.C. Baena, M.K. Nazeeruddin, S.M. Zakeeruddin, W. Tress, A. Abate, A. Hagfeldt, and M. Grätzel, Energy Environ. Sci., 2016, 9, p 1989.

3. S.P. Dunfield, L. Bliss, F. Zhang, J.M. Luther, K. Zhu, M.F.A.M. Hest, M.O. Reese, and J.J. Berry, Adv. Energy Mater., 2020, 10, p 1904054.

4. D.P. McMeekin, G. Sadoughi, W. Rehman, G.E. Eperon, M. Saliba, M.T. Hörantner, A. Haghighirad, N. Sakai, L. Korte,
B. Rech, M.B. Johnston, L.M. Herz, and H.J. Snaith, Science, 2016, 351, p 151.

5. A. Suzuki, H. Okada, and T. Oku, Energies, 2016, 9, p 376.

6. Y. Umemoto, A. Suzuki, and T. Oku, AIP Conf. Proc., 2017, 1807, p 020011.

7. A.D. Jodlowski, C.R. Carmona, G. Grancini, M. Salado, M. Ralaiarisoa, S. Ahmad, N. Koch, L. Camacho, G. Miguel, and M.K. Nazeeruddin, Nat. Energy, 2017, 2, p 972.

8. M.I. Saidaminov, J. Kim, A. Jain, R.Q. Bermudez, H. Tan, G. Long, F. Tan, A. Johnston, Y. Zhao, O. Voznyy, and E.H. Sargent, Nat. Energy, 2018, 3, p 648.

9. J. Tong, Z. Song, D.H. Kim, X. Chen, C. Chen, A.F. Palmstrom, P.F. Ndione, M.O. Reese, S.P. Dunfield, O.G. Reid, J. Liu, F. Zhang, S.P. Harvey, Z. Li, S.T. Christensen, G. Teeter, D. Zhao, M.M.A. Jassim, M.F.A.M. Hest, M.C. Beard, S.E. Shaheen, J.J. Berry, Y. Yan, and K. Zhu, Science, 2019, 364, p 475. 
10. S. Bai, P. Da, C. Li, Z. Wang, Z. Yuan, F. Fu, M. Kawecki, X. Liu, N. Sakai, J.T.W. Wang, S. Huettner, S. Buecheler, M. Fahlman, F. Gao, and H.J. Snaith, Nature, 2019, 571, p 245.

11. A. Suzuki, M. Kato, N. Ueoka, and T. Oku, J. Electron. Mater., 2019, 48, p 3900.

12. Y. Wang, M.I. Dar, L.K. Ono, T. Zhang, M. Kan, Y. Li, L. Zhang, X. Wang, Y. Yang, X. Gao, Y. Qi, M. Grätzel, and Y. Zhao, Science, 2019, 365, p 591.

13. W. Zhao, Z. Yao, F. Yu, D. Yang, and S. Liu, Adv. Sci., 2017, 5, p 1700131.

14. Z. Tanga, S. Uchida, T. Bessho, T. Kinoshita, H. Wang, F. Awai, R. Jono, M.M. Maitani, J. Nakazaki, T. Kubo, and H. Segawa, Nano Energy, 2018, 45, p 184.

15. Y. Chen, N. Li, L. Wang, L. Li, Z. Xu, H. Jiao, P. Liu, C. Zhu, H. Zai, M. Sun, W. Zou, S. Zhang, G. Xing, X. Liu, J. Wang, D. Li, B. Huang, Q. Chen, and H. Zhou, Nat. Commun., 2019, 10, p 1112 .

16. T. Oku, S. Kandori, M. Taguchi, A. Suzuki, M. Okita, S. Minami, S. Fukunishi, and T. Tachikawa, Energies, 2020, 13, p 4776.

17. T. Nakamura, S. Yakumaru, M.A. Truong, K. Kim, J. Liu, S. Hu, K. Otsuka, R. Hashimoto, R. Murdey, T. Sasamori, H.D. Kim, H. Ohkita, T. Handa, Y. Kanemitsu, and A. Wakamiya, Nat. Commun., 2020, 11, p 3008.

18. D. Cortecchia, H.A. Dewi, J. Yin, A. Bruno, S. Chen, T. Baikie, P.P. Boix, M. Grätzel, S. Mhaisalkar, C. Soci, and N. Mathews, Inorg. Chem., 2016, 55, p 1044.

19. N. Ueoka, and T. Oku, ACS Appl. Energy Mater., 2020, 3, p 7272.

20. N. Ueoka, T. Oku, and A. Suzuki, RSC Adv., 2019, 9, p 24231.

21. S. Ye, H. Rao, Z. Zhao, L. Zhang, H. Bao, W. Sun, Y. Li, F. Gu, J. Wang, Z. Liu, Z. Bian, and C. Huang, J. Am. Chem. Soc., 2017, 139, p 7504.

22. K.L. Wang, R. Wang, Z.K. Wang, M. Li, Y. Zhang, H. Ma, L.S. Liao, and Y. Yang, Nano Lett., 2019, 19, p 5176.

23. M.T. Klug, A. Osherov, A.A. Haghighirad, S.D. Stranks, P.R. Brown, S. Bai, J.T.W. Wang, X. Dang, V. Bulovi, H.J. Snaith, and A.M. Belcher, Energy Environ. Sci., 2017, 10, p 236

24. W. Xu, L. Zheng, X. Zhang, Y. Cao, T. Meng, D. Wu, L. Liu, $\mathrm{W}$. $\mathrm{Hu}$, and X. Gong, Adv. Energy Mater., 2018, 8, p 1703178 .

25. X. Gong, L. Guan, H. Pan, Q. Sun, X. Zhao, H. Li, H. Pan, Y. Shen, Y. Shao, L. Sun, Z. Cui, L. Ding, and M. Wang, Adv. Funct. Mater., 2018, 28, p 1804286.

26. H. Zheng, G. Liu, X. Xu, A. Alsaedi, T. Hayat, X. Pan, and S. Dai, Chemsuschem, 2018, 11, p 3269.

27. A. Kooijman, L.A. Muscarella, and R.M. Williams, Appl. Sci., 2019, 9, p 1678.

28. A. Suzuki, and T. Oku, Heliyon, 2018, 4, p e00755.

29. H.X. Zhu, X.H. Wang, and G.C. Zhuang, Appl. Phys. A, 2019, 125, p 45.

30. T. Oku, Rev. Adv. Mater. Sci., 2020, 59, p 264.
31. M. Pazoki, and T. Edvinsson, Sustain. Energy Fuels, 2018, 2, p 1430

32. L. Wang, H. Zhou, J. Hu, B. Huang, M. Sun, B. Dong, G. Zheng, Y. Huang, Y. Chen, L. Li, Z. Xu, N. Li, Z. Liu, Q. Chen, L.D. Sun, and C.H. Yan, Science, 2019, 363, p 265.

33. S. Yang, H. Zhao, Y. Han, C. Duan, Z. Liu, and S.F. Liu, Small, 2019, 15, p 1904387.

34. M.A.P. Osorio, Q. Lin, R.T. Phillips, R.L. Milot, L.M. Herz, M.B. Johnston, and F. Giustino, J. Phys. Chem. C, 2018, 122, p 21703

35. K. Nakada, Y. Matsumoto, Y. Shimoi, K. Yamada, and Y. Furukawa, Molecules, 2019, 24, p 626.

36. J.I. Jaña, R. Muydinov, P. Rosado, H. Mirhosseini, M. Chugh, O. Nazarenko, D.N. Dirin, D. Heinrich, M.R. Wagner, T.D. Kühne, B. Szyszka, M.V. Kovalenko, and A. Hoffmann, Phys. Chem. Chem. Phys., 2020, 22, p 5604.

37. D.J. Kubicki, D. Prochowicz, A. Hofstetter, S.M. Zakeeruddin, M. Grätzel, and L. Emsley, J. Am. Chem. Soc., 2017, 139, p 14173.

38. D.J. Kubicki, D. Prochowicz, A. Hofstetter, S.M. Zakeeruddin, M. Grätzel, and L. Emsley, J. Am. Chem. Soc., 2018, 140, p 7232.

39. E.A. Alharbi, A.Y. Alyamani, D.J. Kubicki, A.R. Uhl, B.J. Walder, A.Q. Alanazi, J. Luo, A.B. Caminal, A. Albadri, H. Albrithen, M.H. Alotaibi, J.E. Moser, S.M. Zakeeruddin, F. Giordano, L. Emsley, and M. Grätzel, Nat. Commun., 2019, 10, p 3008.

40. J.V. Milić, J.H. Im, D.J. Kubicki, A. Ummadisingu, J.Y. Seo, Y. Li, M.A.R. Preciado, M.I. Dar, S.M. Zakeeruddin, L. Emsley, and M. Grätzel, Adv. Energy Mater., 2019, 9, p 1900284.

41. L. Qiu, S. He, L.K. Ono, and Y. Qi, Adv. Energy Mater., 2020, 10, p 1902726.

42. C. Wang, B.R. Ecker, H. Wei, J. Huang, J.Q. Meng, and Y. Gao, Phys. Chem. Chem. Phys., 2017, 19, p 5361.

43. A. Suzuki, and T. Oku, Appl. Surf. Sci., 2019, 483, p 912.

44. A. Suzuki, Y. Miyamoto, and T. Oku, J. Mater. Sci., 2020, 55, p 9728.

45. C. Paschal, A. Pogrebnoi, T. Pogrebnaya, and N. Seriani, SN Appl. Sci., 2020, 2, p 718.

46. C. Zhang, and X. Luo, RSC Adv., 2020, 10, p 23743.

47. T. Liu, Y. Li, S. Feng, W. Yang, R. Xu, X. Zhang, H. Yang, and W. Fu, ACS Appl. Mater. Interfaces, 2020, 12, p 904.

48. A. Ciccioli, and A. Latini, Phys. Chem. Lett., 2019, 9, p 3756.

49. A. Senocrate, G.Y. Kim, M. Gratzel, and J. Maier, ACS Energy Lett., 2019, 4, p 2859.

50. S.K.A. Aal, and A.S.A. Rahman, J. Cryst. Growth, 2017, 457, p 282.

Publisher's Note Springer Nature remains neutral with regard to jurisdictional claims in published maps and institutional affiliations. 